\title{
Neurosteroids in Schizophrenia: Pathogenic and Therapeutic Implications
}

\author{
HuaLin Cai ${ }^{1,2 *}$, Ting Cao ${ }^{1,2}$, Xiang Zhou ${ }^{3,4}$ and Jeffrey K. Yao ${ }^{3,4,5 *}$ \\ 'Department of Pharmacy, The Second Xiangya Hospital of Central South University, Changsha, China, ${ }^{2}$ The Institute of \\ Clinical Pharmacy, Central South University, Changsha, China, ${ }^{3}$ Medical Research Service, VA Pittsburgh Healthcare \\ System, Pittsburgh, PA, United States, ${ }^{4}$ Department of Pharmaceutical Sciences, University of Pittsburgh School of \\ Pharmacy, Pittsburgh, PA, United States, ${ }^{5}$ Department of Psychiatry, University of Pittsburgh School of Medicine, \\ Pittsburgh, PA, United States
}

Neurosteroids are a group of important endogenous molecules affecting many neural functions in the brain. Increasing evidence suggests a possible role of these neurosteroids in the pathology and symptomatology of schizophrenia (SZ) and other mental disorders. The aim of this review is to summarize the current knowledge about the neural functions of neurosteroids in the brain, and to evaluate the role of the key neurosteroids as candidate modulators in the etiology and therapeutics of SZ. The present paper provides a brief introduction of neurosteroid metabolism and distribution, followed by a discussion

OPEN ACCESS

Edited by:

Fei Du,

Harvard Medical School,

United States

Reviewed by: Jennifer C. Felger, Emory University,

United States

Kurt Leroy Hoffman,

Autonomous University

of Tlaxcala, Mexico

*Correspondence:

HuaLin Cai

hualincai@csu.edu.cn; Jeffrey K. Yao jkyao@pitt.edu

Specialty section: This article was submitted to Molecular Psychiatry, a section of the journal Frontiers in Psychiatry

Received: 17 October 2017 Accepted: 21 February 2018 Published: 08 March 2018

Citation:

Cai HL, Cao T, Zhou X and Yao JK (2018) Neurosteroids in Schizophrenia: Pathogenic and

Therapeutic Implications.

Front. Psychiatry 9:73.

doi: 10.3389/fpsyt.2018.00073 of the mechanisms underlying neurosteroid actions in the brain. The content regarding the modulation of the $\mathrm{GABA}_{\mathrm{A}}$ receptor is elaborated, given the considerable knowledge of its interactions with other neurotransmitter and neuroprotective systems, as well as its ameliorating effects on stress that may play a role in the SZ pathophysiology. In addition, several preclinical and clinical studies suggested a therapeutic benefit of neurosteroids in SZ patients, even though the presence of altered neurosteroid pathways in the circulating blood and/or brain remains debatable. Following treatment of antipsychotic drugs in SZ, therapeutic benefits have also been linked to the regulation of neurosteroid signaling. Specifically, the neurosteroids such as pregnenolone and dehydroepiandrosterone affect a broad spectrum of behavioral functions through their unique molecular characteristics and may represent innovative therapeutic targets for SZ. Future investigations in larger cohorts with long-term follow-ups will be required to ascertain the neuropsychopharmacological role of this yet unexploited class of neurosteroid agents.

Keywords: neurosteroids, $\mathrm{GABA}_{\mathrm{A}}$ receptor, metabolism, clinical trial as topic, schizophrenia

\section{INTRODUCTION}

The term "neurosteroid," first introduced by Baulieu and Robel (1), refers to the steroids that are synthesized in the brain. The term "Neuroactive steroid" subsequently introduced in 1992 by Paul and Purdy (2) has a broader concept, which refers to those steroids that are produced by an endocrine gland and subsequently reach the brain through the bloodstream. Now the two terms coexist and are mutually complemented (3). Based on the differences in activity and structure, the neurosteroids can be categorized into the following classes: pregnane neurosteroids [allopregnanolone (ALLO) and allotetrahydrodeoxycorticosterone (THDOC)], androstane neurosteroids (androstanediol and etiocholanone), and sulfated neurosteroids [pregnenolone sulfate (PS) and dehydroepiandrosterone sulfate (DHEAS)] (4).

Since the neurosteroids are highly lipophilic, they can easily pass the blood-brain barrier and modulate neuronal excitability and functioning through interactions with ligand-gated ion channels 
and other cell surface receptors (4). Some of these steroids may exert additional effects on gene expression via nuclear steroid hormone receptors (4). Growing data lend further support to the notion that neurosteroid dysregulation plays a crucial role in the pathophysiology of several psychiatric disorders, and may be a therapeutic target for antipsychotic treatment $(3,5-8)$.

Moreover, some neurosteroids have been demonstrated to possess anxiolytic, antidepressant and/or antipsychotic properties in animals (9-11). At the cellular level, they may exert neuroprotective effects, such as stimulating neurogenesis or facilitating the regeneration of neurons after injury, as well as promoting myelination (12-14). In animal models, as evaluated by the performance on memory tasks (15-19), specific neurosteroids have also been linked to the cognitive function. Taken together, it is likely that neurosteroids may serve as a potential therapeutic target for attention deficit hyperactivity disorder, Parkinson's disease, depression, anxiety disorders, and schizophrenia (SZ) (20-23).

Schizophrenia is a remarkably complex disorder with diverse behavioral symptoms and biological perturbations. Whether these alterations are independent biological processes or a combined result of a more fundamental pathology has yet to be determined. The dopamine hypothesis of SZ has been one of the most enduring ideas in psychiatry. It has been focused on the role of hyperdopaminergia initially, redefined to specify subcortical hyperdopaminergia with prefrontal hypodopaminergia subsequently, and characterized as a "final common pathway" recently, in the etiology of SZ (24). More recently, a more integrative view combines different neurotransmitter systems, in which glutamatergic, GABAergic (gama-aminobutyric acid), and dopaminergic pathways interact (25). Thus, hypofunction of the $N$-methyl-D-aspartate (NMDA) type glutamate receptor, possibly on critical GABAergic interneurons, may also contribute to the pathophysiology beyond dopaminergic dysfunction of SZ (26). In addition, many other theories have been proposed in SZ over the years that aim to characterize the inherent pathological processes related to altered neurotransmission and signal transduction, including autoimmune dysfunction, membrane phospholipids deficits, etc. (27-32). However, many metabolic pathways which are likely modified by current treatment and of what relevance they are to clinical outcome remain unclear.

Thus, the issue at hand, first, is to identify candidate biological process(es) that are associated with SZ. The complex roles of neurosteroids in bipolar disorder (33), major depression (22, 34 ), anxiety disorder (22), pain (35), epilepsy (36), and autism spectrum disorder (37) have already been extensively discussed in separate reviews. The present review explores a potential role of neurosteroids in a specific metabolic pathway (pregnenoloneprogesterone-allopregnanolone pathway) that may provide innovative targets for therapeutic intervention and monitoring in SZ.

\section{NEUROSTEROIDS IN THE BRAIN}

Neurosteroids are biosynthesized in both the central and peripheral nervous systems, from cholesterol or through conversion of peripherally derived adrenal or gonadal steroids. The initial steps of de novo steroid biosynthesis include the translocation of cholesterol into the inner mitochondrial membrane and subsequent cleavage of cholesterol side-chain into pregnenolone (PREG) by enzyme CYP11A1 (cytochrome P450scc) (38). Conversion of cholesterol to PREG is the first rate-limiting step in the biosynthesis of all steroid hormones (38). The existence of several other key steroidogenic enzymes has now been identified in the human brain (38). These include the $3 \beta$-hydroxysteroid dehydrogenase, $17 \alpha$-hydroxylase, 17,20 -lyase, $17 \beta$-hydroxysteroid dehydrogenase (17 $\beta$-HSD), $5 \alpha$-reductase (5 $\alpha-\mathrm{R}), 3 \alpha$-hydroxysteroid dehydrogenase, cytochrome P450 aromatase (P450arom), as well as hydroxysteroid sulfotransferase (HST) (38). Most of these enzymes are involved in de novo steroidogenesis in the brain. P450arom and $5 \alpha-\mathrm{R}$, however, are mainly responsible for the conversion in the brain of hormonal steroids originating from peripheral endocrine glands. The schematic diagram illustrating the neurosteroid pathways in the neuron or glial cell is shown in Figure 1.

Although locally synthesized neurosteroids play a major role as signaling molecules in the brain, the regulating mechanisms underlying the neurosteroid biosynthesis remain unclear. A previous study (39) indicated that the expression and activity of key steroidogenic enzymes in the brain may be regulated by adrenal and gonadal steroids, suggesting a putative association between peripheral and brain neurosteroids. Furthermore, their findings suggest that the neurosteroids in the periphery can serve as a proxy or surrogate marker for the regulation of neurosteroids in the brain. In fact, positive correlations between plasma and brain levels of neurosteroids have been demonstrated in rat (40, 41). A similar correlation has also been observed between plasma and CSF in humans (42).

\section{MECHANISMS UNDERLYING NEUROSTEROID ACTIONS}

Increasing evidence suggests that neurosteroids play a pivotal role in the development and functioning of the brain. In general, neurosteroids exert their genomic actions by targeting the intracellular receptors within the nucleus or cytoplasm. However, metabolites of progesterone (PROG) together with several other stress hormones can act on the membrane receptor through a non-genomic mechanism. In contrast to the genomic action of neurosteroids which is limited by protein synthesis, the modulation of the membrane receptor is fast occurring and only requires milliseconds to seconds (43). To date, it is well known that certain neurosteroids can non-genomically alter neuronal excitability in the brain via GABA neurotransmitter system (44). The receptors in several other neurotransmitter systems such as NMDA, dopaminergic, and sigma-1 receptors are also the targets for neurosteroids (45). The present review intends to underscore the critical role of neurosteroids [specifically, PROG and its $5 \alpha$-reduced metabolites, as well as sulfated prognenolone and dehydroepiandrosterone (DHEA)] in the regulation of the neurotransmitter systems.

\section{Modulation of $\mathrm{GABA}_{\mathrm{A}}$ Receptors}

The $\mathrm{GABA}_{\mathrm{A}}$ receptor is responsible for the primarily inhibitory currents in the brain (46). Neurosteroid actions at the $\mathrm{GABA}_{\mathrm{A}}$ 


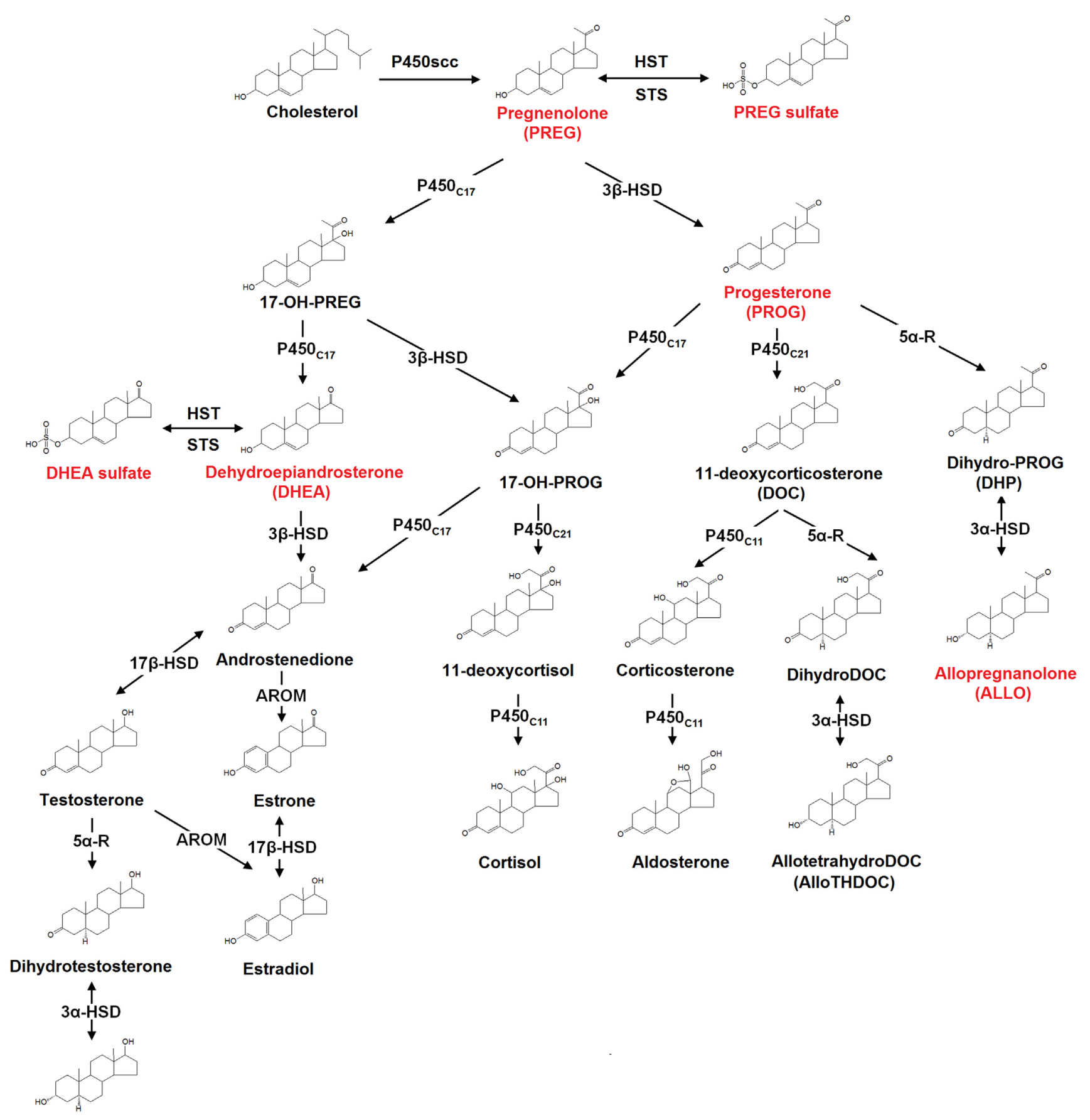

Androstanediol

FIGURE 1 | The biosynthesis pathways of neurosteroids in the human brain. Abbreviations: AROM, aromatase; HST, sulfotransferase; STS, sulfatase; P450scc, cytochrome P450 side-chain cleavage; P450c11, cytochrome P450 11 -hydroxylase/18-hydroxylase/18-methyl oxidase; P450c17, cytochrome P450 17 $\alpha$ -

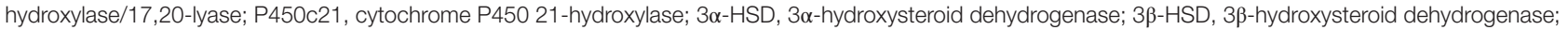
$5 \alpha$-R, $5 \alpha$-reductase; $17 \beta-H S D, 17 \beta$-hydroxysteroid dehydrogenase. Those neurosteroids having the potential therapeutic roles in schizophrenia are highlighted in red in the figure.

receptor complex have received increasing attention, given the extensive data published regarding the interactions between the specific neurosteroids and this receptor and its intimate involvement in different psychiatric illnesses.
Neurosteroids can rapidly alter neuronal excitability via direct interactions with $\mathrm{GABA}_{\mathrm{A}}$ receptors and hence are often considered as endogenous modulators of $\mathrm{GABA}_{\mathrm{A}}$ receptors in the brain $(46-48)$. The $\mathrm{GABA}_{\mathrm{A}}$ receptor is a ligand-gated chloride channel 
typically comprised of two $\alpha$, two $\beta$, and either one $\gamma$ or one $\delta$ subunits (Figure 2).

\section{Binding Sites of GABA $A$ Receptor}

The GABA binding site is located in the cleft between the $\alpha$ and $\beta$ subunits (49). When activated by the endogenous neurotransmitter GABA, the neurons will be hyperpolarized through influx of chloride ions (49). Apart from the GABA site, there are many other binding sites clustered at the $\mathrm{GABA}_{\mathrm{A}}$ receptor which are targeted by depressant/sedative agents, like benzodiazepines and barbiturates (49). Each pharmacological effect appears to be linked to a specific binding site on the receptor surface, depending on the subunit composition of the receptor. For instance, sedation has been linked to an enhancement at $\alpha_{1}$ subunit, whereas anxiolytic action is associated with the $\alpha_{2}$ subunit (50). Previous data have further shown that the $\alpha_{5}$ subunit largely contributes to sedative tolerance development to benzodiazepines and formation of associative memory and spatial learning (51-54), whereas the $\alpha_{4}$ subunit takes part in the regulation of anxiety (55) and the $\alpha_{6}$ subunit is relatively more responsive to pentobarbital (56) and neurosteroids (57). Alpha 1-5 subunits are also responsive to neurosteroids. In general, previous studies indicated that the neurosteroid (ALLO) enhanced GABA-evoked responses with all $\alpha$ subunit isoforms $\left(\alpha_{1-6 \beta 1 \gamma 2}\right)(58,59)$. As revealed by Belelli et al. $(60)$, ALLO produced about sixfold to sevenfold enhancement of the $\operatorname{GABA}\left(\mathrm{EC}_{10}\right)$-evoked response for $\alpha_{x \beta 1 \gamma 2}(x=1-5)$ type $\mathrm{GABA}_{\mathrm{A}}$ receptors, whereas for receptors incorporating the $\alpha_{6}$ subunit, ALLO increased the current by 12 -fold to the $\operatorname{GABA}\left(\mathrm{EC}_{10}\right)$ evoked response. On the other hand, it should be noted that the neurosteroid sensitivity of $\alpha_{4}$ subunit containing receptor is also dependent upon the other partner subunits, as $\alpha_{4}$ receptors incorporating the $\delta$ subunit are highly steroid sensitive (60). By contrast, the isoform of the $\beta$ subunit (1-3) has little impact on the GABA-modulatory actions of the neurosteroids (60).

The postsynaptic $\mathrm{GABA}_{\mathrm{A}}$ receptors usually contain the $\gamma$ subunit and are sensitive to both benzodiazepines and neurosteroids (44). Physically, they are ubiquitously distributed in the brain to generate the phasic currents in response to the GABA released from vesicle. The presence of the $\gamma$ subunit within the $\mathrm{GABA}_{\mathrm{A}}$ receptor is not a prerequisite for neurosteroid activities (60). Actually, a comparison of ALLO modulation of GABA responses mediated by $\alpha_{1 \beta 1}$ and $\alpha_{1 \beta 1 \gamma 2}$ receptors indicates that the former is more responsive, increasing the GABA-evoked response above the apparent maximal response to $\operatorname{GABA}(59,60)$. The isoform of the $\gamma$ subunit has little, or no effect on the maximal GABA-modulatory effect of ALLO, but significantly influences the potency of the neurosteroid, suggesting that the $\gamma_{1}$ subunit containing $\mathrm{GABA}_{\mathrm{A}}$ receptors are less effective than $\gamma_{2}$ subunit containing $\mathrm{GABA}_{\mathrm{A}}$ receptors $(59,60)$.

The extrasynaptic $\mathrm{GABA}_{\mathrm{A}}$ receptors, however, are preferentially activated when GABA levels are low and ambient because of their high GABA affinity in comparison with the postsynaptic $\mathrm{GABA}_{\mathrm{A}}$ receptors $(61,62)$. The extrasynaptic $\mathrm{GABA}_{\mathrm{A}}$ receptors containing the $\delta$ subunit are expressed in various brain regions including the hippocampus, thalamus, amygdala, hypothalamus, and cerebellum (63). These extrasynaptic receptors generate non-desensitizing tonic inhibition currents that are highly sensitive to the extracellular GABA concentration (64). Tonic current controls the baseline excitability and generates shunting

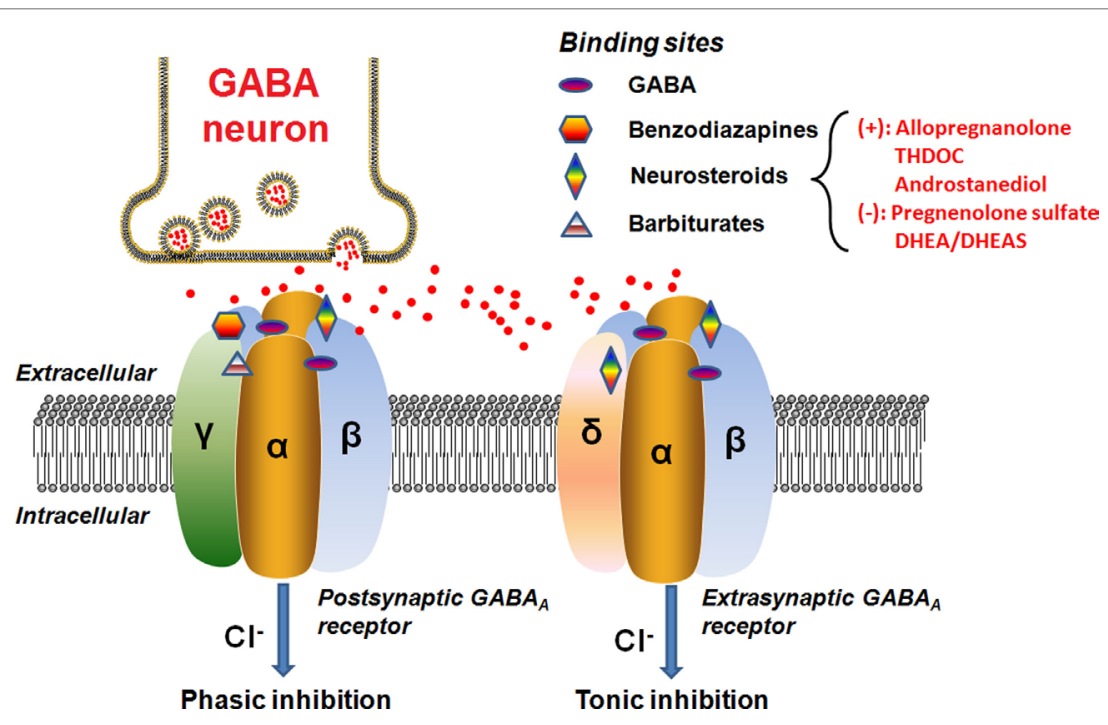

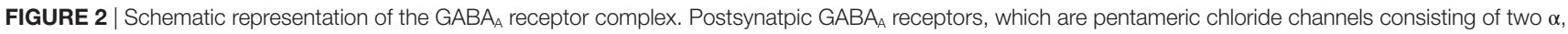
two $\beta$, and one $\gamma$ subunits, mediated the phasic GABAergic inhibition, whereas extrasynaptic GABAA receptors, pentamers composed of two $\alpha$, two $\beta$, and one $\delta$ subunits, primarily contribute to tonic inhibition. Neurosteroids activate both postsynaptic and extrasynaptic receptors to enhance the phasic and tonic inhibition, and thereby promote maximal net inhibition. The GABA receptors have distinct binding sites for numerous molecules, as illustrated in the figure. The typical neurosteroids that modulate positively $(+)$ or negatively $(-)$ on the GABA receptor complex at the synaptic membrane of nerve cells are indicated. The red dots represent the GABA neurotransmitter molecules released from the vesicles of the GABA neuron synapse. Abbreviations: GABA, $\gamma$-aminobutyric acid; THDOC, tetrahydrodeoxycorticosterone; DHEA, dehydroepiandrosterone; DHEAS, dehydroepiandrosterone sulfate. 
inhibition in the dentate gyrus, which is a critical region controlling afferent neuronal inputs and contributing to the formation of memories $(46,65,66)$. Additional findings further indicate that the extrasynaptic receptors within specific brain regions (e.g., hypothalamus, hippocampal dentate gyrus, and cerebellum) are highly sensitive to neurosteroids, which may provide us with an important therapeutic target for neurosteroids (64). Initially, it was reported that the incorporation of the $\delta$ subunit reduced the GABA-modulatory actions of the neurosteroids (67). Subsequently, several studies demonstrated that the $\delta$ subunit greatly enhanced the steroid sensitivity of the receptor for some subunit combinations $(60,68,69)$. The underlying reasons for these discrepancies are unknown. However, the $\delta$ subunit is known to associate with the $\alpha_{6}$ subunit in cerebellar granule cells and with the $\alpha_{4}$ subunit in thalamus and dentate gyrus granule cells of the hippocampus (60). Therefore, such tonic currents greatly influence neuronal excitability and hence may be an important locus of neurosteroid actions (70).

The exact neurosteroid binding sites on the $\mathrm{GABA}_{\mathrm{A}}$ receptor remain to be characterized. It is not known whether $\gamma$ and $\delta$ subunits have functional neuroteroid binding sites. However, the initial findings suggest at least two separate binding sites for neurosteroids consisting of an allosteric site within the $\alpha$ subunit and a direct activation site at the $\alpha-\beta$ subunit interface (71). Such distinctive binding sites further lead to the agonistic and antagonistic actions. For example, ALLO, allotetrahydrodeoxycorticosterone, and androstanediol are potent positive allosteric modulators of $\mathrm{GABA}_{\mathrm{A}}$ receptors (4), whereas sulfated neurosteroids like PS and DHEAS have inhibitory actions on $\mathrm{GABA}_{\mathrm{A}}$ receptors $(4,72)$. Further, the agonistic actions can be differentiated into direct activation or allosteric enhancement of $\mathrm{GABA}_{\mathrm{A}}$ receptors $(70,73)$.

\section{Modulation of $\mathrm{GABA}_{\mathrm{A}}$ Receptor by Neurosteroids}

The modulatory effects of neurosteroids on the $\mathrm{GABA}_{\mathrm{A}}$ receptor are complex, and depend on the type and structure of the steroids, as well as on the location and subunit compositions of the receptors.

Neurosteroids have a unique action mode: at high concentrations $(\geq 1 \mu \mathrm{M})$, neurosteroids directly activate $\mathrm{GABA}_{\mathrm{A}}$ receptors to attain ceiling value by occupying all available neurosteroid binding sites, whereas at low concentrations $(<1 \mu \mathrm{M})$, they allostericallly potentiate $\mathrm{GABA}_{\mathrm{A}}$ receptor currents at a limiting value by fully occupying the allosteric site (44). Therefore, the overall net GABAergic inhibition contributed by neurosteroid-induced activation of $\mathrm{GABA}_{\mathrm{A}}$ receptors may occur through allosteric and direct activation mechanisms. Despite increasing evidence shows that many neurosteroids and other medications can modulate $\mathrm{GABA}_{\mathrm{A}}$ receptor functions, the relationship between the chemical structure of neurosteroids and their biological activities on the $\mathrm{GABA}_{\mathrm{A}}$ receptor remains to be elucidated.

To date, systematic investigations of neurosteroids have identified the following structural characteristics that confer their activity at the $\mathrm{GABA}_{\mathrm{A}}$ receptor (74-76): (1) the scaffold geometry at the A/B ring; (2) a hydrogen-bond donator in $\mathrm{C} 3$ position which is indispensable for the binding affinity and the enhancing functions of neurosteroids; (3) the stereoselectivity of
C5 $\alpha-\mathrm{H}$ which may affect the potency of the neuorsteroids; and (4) a hydrogen-bond acceptor in C20 position or a flexible bond at $\mathrm{C} 17$ position is important for high-potency positive allosteric modulation (Figure 3). Currently, over 500 synthetic analogs based on neurosteroid structures have been screened for brain activity (77).

\section{Modulation of Glutamate Receptors}

Previous studies have shown that the NMDA receptor can be regulated by specific neurosteroids $(78,79)$. The NMDA receptor possesses at least two distinct sites for neurosteroids, which differentially mediate the effects of positive modulators and the effects of negative modulators (80). Sulfated neurosteroids, such as PS and DHEAS, appear to be potent allosteric agonists on the NMDA receptor complex.

Initial data from electrophysiological experiments have also indicated that PS modulation of the NMDA receptor may be attributed to its ability to increase the frequency and duration of NMDA-activated channels opening (81). Subsequently, recombinant NMDA receptors with specific subunit compositions have demonstrated that mechanisms underlying the actions of PS on NMDA receptors are more complex. PS is able to potentiate NMDA receptor subunits GluN1/GluN2A and GluN1/GluN2B, as well as inhibit GluN1/GluN2C and GluN1/GluN2D subunits (82). Thus, the overall effect of PS on NMDA receptors will depend upon the binding affinities as well as the composition of NMDA

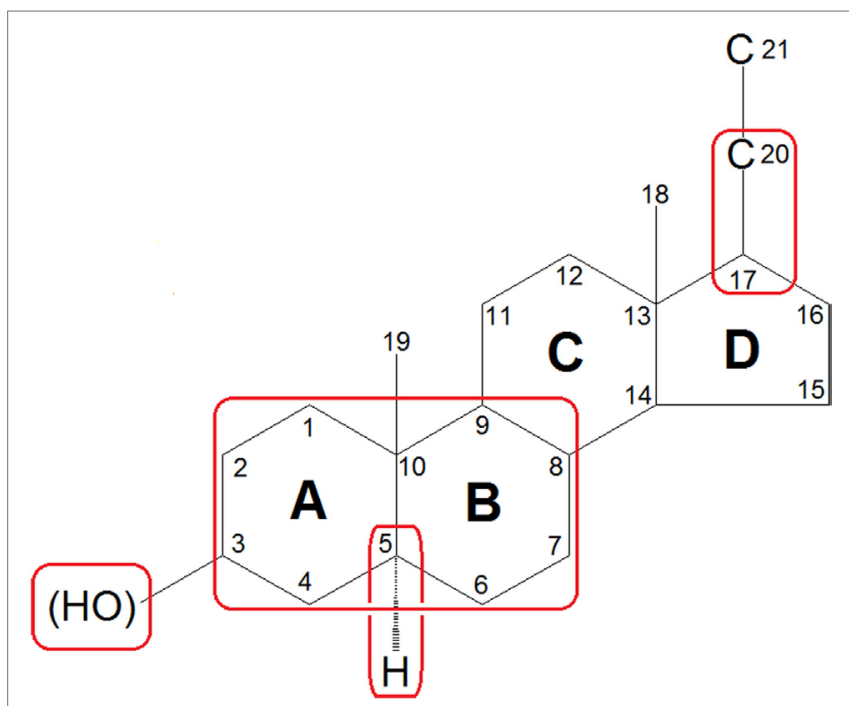

FIGURE 3 | Features of general neurosteroid structure with the rings and carbon positions labeled. Hydroxyl groups are denoted $\beta$ if they are oriented above the plane (solid line) and $\alpha$ if they are oriented below the plane (dashed line). GABA $A_{A}$ receptor-activated neurosteroids have the following structural requirements as highlighted with red rounded rectangle: (1) the scaffold geometry at the A/B ring; (2) a hydrogen-bond donator in C3 position which is indispensable for the binding affinity and the enhancing functions of neurosteroids; (3) the stereoselectivity of $\mathrm{C} 5 \alpha-\mathrm{H}$ which may affect the potency of the neuorsteroids; and (4) a hydrogen-bond acceptor in C20 position or a flexible bond at C17 position is important for high-potency positive allosteric modulation. 
receptor subunits (79). Since most available studies were carried out in neurons where NMDA receptor with GluN1/GluN2A and GluN1/GluN2B subunits are predominant, PS and DHEAS were often considered to be solely potentiating, rather than inhibiting compounds (79).

Additionally, PS is a typical representative member of neurosteroids that have indirect potentiating effects on NMDA receptors mediated through the inhibition of AMPA, kainate, and $\mathrm{GABA}_{\mathrm{A}}$ receptors $(83,84)$.

\section{Modulation of Dopaminergic Activity and Sigma Receptors}

Accumulating data suggest a role of the neurosteroids, especially PROG, in modulating the dopamine system either directly, or indirectly through the GABAergic system. Several previous studies have reported that: (1) a single dose of PROG can increase the levels of dopamine and its metabolites in the striatum of male rats (85) and the extracellular levels of striatal dopamine (86); (2) systemic administration of PROG also stimulates the release of dopamine in the striatum of intact male as well as ovarectomized female rats (86) and increases ethanol-induced mesocortical dopaminergic activity (87); (3) in women, PROG can increase the dopaminergic activity in amygdala (88); and (4) PROG also exhibited neuroprotective effects on the dopaminergic system of mice during degeneration (89).

On the other hand, other endogenous neurosteroids may modulate the dopaminergic signaling in opposite ways. Allopregnanolone diminishes dopaminergic neurotransmission through the modulation of basal and stress-induced dopamine release in the rat cerebral cortex and nucleus accumbens (90). Several other studies have demonstrated that increased brain levels of ALLO can dampen the release of dopamine in rat brain dopaminergic regions $(90,91)$. Similarly, benzodiazepine receptor agonists can suppress dopaminergic activity via $\mathrm{GABA}_{\mathrm{A}}$ receptors in the striatum (92). Moreover, low doses of ALLO increase dopamine release, while higher doses decrease it, thereby exerting a dual modulatory effect on the dopaminergic nigro-striatal system (93). It is possible that via activation of the $\mathrm{GABA}_{\mathrm{A}}$ receptor, ALLO directly influences dopaminergic transmission through intracellular signaling mechanisms such as activation of protein kinases $(94,95)$. Electrophysiological findings from rat brain slices lend further support that a bidirectional mechanism consisting of both GABAergic and glutamatergic inputs underlies the firing pattern of dopaminergic neurons (96).

Studies on binding affinity and pharmacological effects have revealed that certain neurosteroids (PS, DHEAS, and PROG) interact with sigma receptors, which are also present in high densities in the brain $(97,98)$. DHEAS and PS act as agonists, whereas PROG functions as an antagonist (99) on sigma receptors. Actions of PS and DHEAS on selective sigma-1 receptors may exhibit a potent modulating effect on excitatory neurotransmitter systems, such as the glutamatergic and cholinergic systems (98). Selective sigma-1 receptor ligands can modulate NMDA-mediated glutamatergic neurotransmission. This modulation plays a pivotal role in various neuroadaptational phenomena, including seizures, long-term potentiation, learning and memory, acute neuronal death, and neurodegeneration (99).

\section{Neurosteroid-Induced Neuroprotection}

Although SZ is not conceptualized as a typical degenerative disorder, a large body of evidence suggests that, in a subset of SZ patients, glutamate-mediated excitotoxicity occurs in certain hippocampal and cortical areas $(100,101)$. Patients with SZ who have excitotoxic damage would be expected to present poor outcomes characterized by anatomical evidence of progressive neurodegeneration, pronounced negative symptoms and cognitive deficits, and profound psychosocial deterioration (102).

Neurosteroids have demonstrated neuroprotective effects in both central and peripheral nervous system by attenuating excitotoxicity, brain edema, inflammatory processes, oxidative stress, and neural degeneration (103). Additionally, neurosteroids accelerate and improve neurogenesis and myelination $(103,104)$. Previous findings have also advanced that PREG, a neurosteroid precursor, exhibits neuroprotective effects against glutamate-induced neurotoxicity (105), stabilizes microtubules (106), enhances polymerization and activates neurite outgrowth (107), and improves myelination (108). Meanwhile, the neuroprotective effects of both DHEA and DHEAS may be attributed to their modulatory effects on $\mathrm{GABA}_{\mathrm{A}}$ receptors (109) and protection of mitochondria against intracellular $\mathrm{Ca}^{2+}$ overload (110). In addition, several studies have revealed the neuroprotective effects of PROG in experimental crush-induced injury, mediated by increases in brain derived neurotrophic factor (BDNF) (111), preventing secondary neuronal loss (112), as well as by restoring impaired expression of choline acetyltransferase and $\mathrm{Na}$, K-ATPase subunits (113). The neuroprotective effects of PROG may be mediated through its metabolite ALLO: in experimental injury models, ALLO levels increased after PROG administration, and the neuroprotective effect of PROG was diminished by inhibition of ALLO biosynthesis $(114,115)$.

On the other hand, another plausible mechanism by which neurosteroids could exert neuroprotective effects involves their capacity to modulate polyunsaturated fatty acid (PUFA) metabolism. As a major component of neuron membranes in the brain, long-chain PUFAs play a key role in the maintenance of brain functions, and dysregulation of PUFAs has consistently been observed in SZ $(27,29,32)$. Estradiol is able to enhance the synthesis of linolenic acid elongation products, including eicosapentaenoic acid, docosapentaenoic acid, and docosahexaenoic acid in neuroblastoma cells, thereby suggesting that neurosteroids may regulate PUFA synthesis (116). In addition, PROG treatment counteracted several parameters related to decreased synaptic plasticity (BDNF, syntaxin-3, growth associated protein-43, myelin-associated glycoprotein, etc.), and membrane stability (4-hydroxynonenal and secreted phospholipases $A_{2}$ ) resulting from n-3 PUFA deficiency, which can suggest potential targets for therapeutic applications (12).

\section{Ameliorating Stress Response}

The neuroendocrine response to stress is mediated through the hypothalamic-pituitary-adrenal (HPA) axis (117). Accumulating evidence suggests that the perception of stress by patients with SZ is sufficiently altered so as to lead to a more frequent activation of the primary stress response, namely hyperactivity of the HPA axis 
(118). It is likely that HPA axis dysfunction not only contributes to the manifestation and exacerbation of symptoms (119) but also to the pattern of poor physical health and premature mortality in SZ patients (117).

The effects of neurosteroids on the stress response may be associated with negative feedback and self-protective mechanisms (21). Acute stress is stimulated in animal models by mild carbon dioxide exposure, foot shock, or forced swimming; these manipulations transiently change the levels of several neurosteroids in both the brain and plasma. Along with corticosterone, an indicator of HPA activation in rodents, levels of PREG, PROG, THDOC, and ALLO are significantly increased in the brain and plasma of acutely stressed animals (120-125). Interestingly, inhibition or complete blockade of GABAergic neurotransmission mimicked the behavioral and physiological effects of stress in rodents, such as inducing anxiety-like behavior (126) and increasing brain and plasma levels of ALLO, THDOC, and cortisol (40, 122, 123). Such effects, however, can be reversed by pretreatment with a positive modulator of the $\mathrm{GABA}_{\mathrm{A}}$ receptor $(122,123)$.

It is also possible that a feedback mechanism involving stressinduced increases of ALLO and THDOC could antagonize the suppressive effect of stress on GABAergic transmission $(2,120$, 127). Since it is well documented that GABAergic transmission exerts inhibitory effects on HPA axis activity, a diminished GABAergic tone may contribute to the hyperactivity of HPA axis (120). Therefore, increased concentrations of ALLO and THDOC would result in an upregulation of the GABAergic tone, which ameliorates the HPA axis activity.

The effects of chronic stress on neurosteroid concentrations differ from those of acute stress. Mild chronic stress, induced in rodents by social isolation or a combination of several unpredictable stimuli, can cause a significant decrease in PREG, PROG, ALLO, and THDOC in both the brain and plasma (128-131), whereas DHEA levels are unaffected (128). Neurosteroid alterations were non-significant after a 48 -h short term of chronic stress, but after a long-term chronic stress, decrements were shown after 7 days and the trend persisted for 30 days (128). Chronic stress was also related to a decrease in GABAergic signaling (128), which could lead to the loss of inhibition of HPA axis activity $(132,133)$.

\section{POTENTIAL ROLES OF NEUROSTEROIDS IN SZ}

Accruing evidence from animal models of SZ as well as from patients with SZ suggests that certain key neurosteroids and selected metabolites may play a role in the pathophysiology and therapeutics of SZ (21). The initial findings indicate that PREG administration result in elevations of PS in rodent brain and plasma (134) and of PS and DHEAS in serum of human subjects (135). In addition, the concentrations of downstream metabolites PROG and ALLO in human serum are increased following PREG administration (135). Given the various mechanisms of action that neurosteroids have on the brain, the potential role of neurosteroids of the PREG metabolic pathway should be explored in the context of SZ (Figure 4).

\section{Neurosteroid Deficits in SZ Patients}

Schizophrenia has been linked to a variety of aberrant functions related to HPA axis $(117,136)$, dopaminergic signaling (137), glutamatergic system (26) and GABAergic system (138). Interestingly, neurosteroids are able to modulate these deficits as well as the sigma-1 system, directly and/or indirectly (99), and thus may be involved in the pathophysiology of this disabling illness. Regulation of these neurosteroids may also contribute to the therapeutic benefits of antipsychotics, especially those which act on the $\mathrm{GABA}_{\mathrm{A}}$ receptor complex $(139,140)$.

\section{Pregnenolone-Progesterone-Allopregnanolone Pathways}

Converging evidence indicates a pattern of reduced PROG and its related endogenous steroids in SZ. Lower levels of serum PREG (141) were found in SZ patients as compared with healthy controls (HC). Moreover, metabolic stress induced by injection of 2-deoxyglucose caused a significantly greater increase in plasma PROG of SZ patients than HC (142). Preliminary evidence suggests that plasma ALLO may be decreased in nonmedicated first-episode SZ patients (135). Evidence from a postmortem study showed a decrement in ALLO levels in the parietal cortex of SZ patients compared to HC (8). However, inconsistent findings were also reported, showing that plasma PROG levels may be lower, or similar in SZ patients when compared to HC (143-145).

Finally, a proof-of-concept trial was conducted with adjunctive PREG administered to SZ patients, with cognition and negative symptoms being the outcomes of interest (135). Increases in levels of serum PREG and ALLO predicted Brief Assessment of Cognition in schizophrenia (BACS) composite scores after 8 weeks of treatment with PREG. In addition, baseline PREG, PS, and ALLO levels were inversely correlated with the improvement in MATRICS Consensus Cognitive Battery (MCCB) composite scores, lending further support to the notion that neurosteroids play a significant role in SZ-related cognitive dysfunction (135).

\section{Transformation from DHEA to DHEA Sulfate}

Abnormalities in the conversion of DHEA to DHEAS have also been implicated in SZ. The earlier studies reporting decreased plasma DHEA levels in SZ patients $(146,147)$ were questionable due to methodology issues. However, the later studies with improved methodology have shown elevated levels of plasma DHEA and DHEAS in severely psychotic male subjects (148), chronic SZ patients under treatment (149), and firstepisode drug-naïve patients (150). A recent finding suggests that increased serum DHEAS may exist only in the first-episode but not in subsequent recurrences of male SZ patients (151), which is not in accordance with the earlier study using a state-of-art gas chromatography-mass spectrometry method (145).

As compared to DHEA or DHEAS alone, it has been suggested that the ratio of DHEA/cortisol or DHEAS/cortisol may be more useful indicators (152). Ritsner et al. (153) reported that the ratios of DHEA/cortisol and DHEAS/cortisol were higher in SZ patients than in $\mathrm{HC}$, whereas the ratio of DHEA/cortisol remained unchanged in another cohort of SZ patients (154). Moreover, lower levels of circulating DHEAS (150), DHEA and 


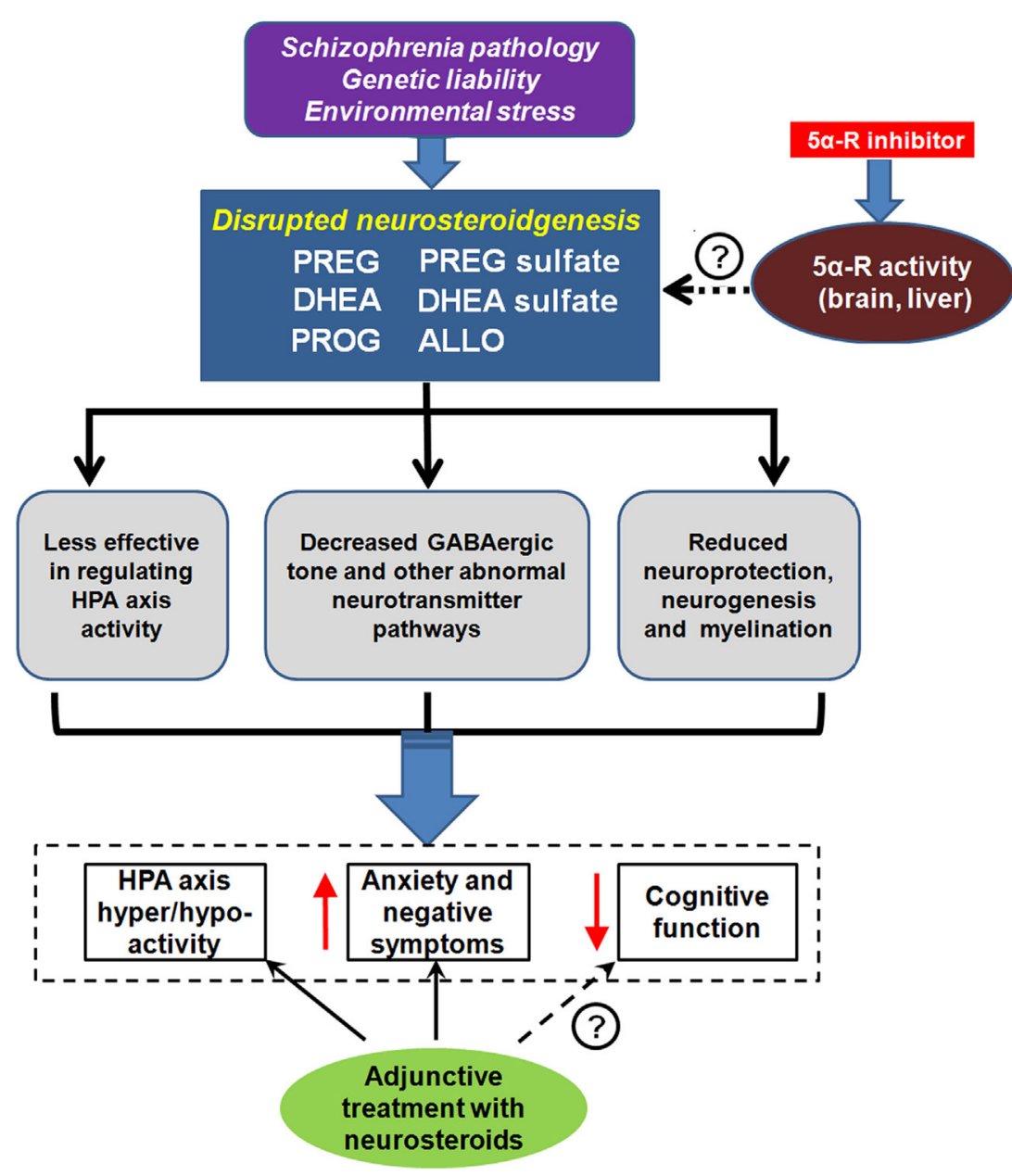

FIGURE 4 | Neurosteroids and schizophrenia (SZ). Unknown SZ pathology, genetic liability, and/or environmental stress may lead to disrupted neurosteroidgenesis, which is manifested by abnormalities in several key neurosteroids, including pregnenolone (PREG), PREG sulfate, dehydroepiandrosterone (DHEA), DHEA sulfate, progesterone (PROG), and allopregnanolone (ALLO). This disruption is associated with dysregulation of the hypothalamic-pituitary-adrenal (HPA) axis, aggravated anxiety, and negative symptoms, as well as impairment in cognition. Some of the symptom domains can be reversed with neurosteroid argumentation. $5 \alpha-$ reductase $(5 \alpha-R)$ is a rate-limiting enzyme involved in neurosteroid metabolism. Recent pharmacological studies revealed that the inhibition of $5 \alpha-R$ activity by $5 \alpha-R$ inhibitor could prevent quick exhaustion of the aforementioned neurosteroids. Thus, $5 \alpha-R$ may be a new promising target for SZ treatment. $\uparrow$ indicates increased and $\downarrow$ indicates decreased.

the ratio of DHEA/cortisol were correlated with higher severity of symptomatology in SZ patients (155). Consequently, high levels of circulating DHEA and/or DHEAS may reflect a better functioning in SZ patients, though it is paradoxical that several abovementioned studies showed that this population has higher DHEA and/or DHEAS levels than matched controls (148-150).

In sum, dysregulated neurosteroids may be related to some physiological and/or functional alterations in SZ. First, decreases in brain levels of ALLO, which positively modulates GABAergic transmission, in combination with elevations of DHEA and DHEAS, which negatively modulated GABAergic activity, could lead to impairments of GABAergic function that are observed in SZ. Second, excessive serotonergic activity in SZ patients (156) may result from low levels of PROG and ALLO, antagonists of the $5-\mathrm{HT}_{3}$ receptor (157). Third, neurosteroids targeting sigma-1 receptors may be beneficial in the treatment of SZ patients (158). For instance, increases in DHEA and DHEAS levels [positive sigma-1 receptor modulators $(98,99)]$, in combination with decreased concentrations of PROG [an antagonist of sigma-1 receptor (99)], may play a role in the pathophysiology of SZ. In addition, it has been shown that DHEA and DHEAS can stimulate NMDA receptor activity, which may be in part responsible for the hyperactivity and subsequently reduced density of NMDA receptor in SZ (159).

\section{THERAPEUTIC PROPERTIES OF NEUROSTERIODS}

\section{Neurosteroids in Experimental Models Effects on Learning and Memory in Animal Behavioral Models}

It is well known that cognitive functions profoundly impact on the outcome and long-term quality of life in SZ patients $(17,18$, 
160-162). The neurosteroids appear to exhibit positive effects on learning and memory $(17,18,163,164)$ at physiologically relevant concentrations (165). Further, the improvements in learning and memory dysfunctions have been demonstrated in several behavioral animal models after treatment with neurosteroids $(16,166$, 167).

Selective NMDA receptor antagonists are often used to model the putative state of SZ and its therapeutic outcome $(168,169)$. Since NMDA receptor antagonists such as ketamine not only induce psychotic-like symptoms in healthy volunteers but also exacerbate psychotic symptoms in SZ patients $(170,171)$, these neurosteroid actions may be of particularly relevance to the pathophysiology of SZ, and to the treatment of cognitive symptoms. Specifically, PS administration can prevent the deficits in learning and memory resulting from NMDA receptor antagonists, including MK-801, dizocilpine and scopolamine (172-175). Like PS, the GABAergic ALLO is also able to ameliorate the MK-801-induced behavioral effects $(176,177)$. In short, several neurosteroids have played a role in the reversal of MK-801-induced behavioral changes, which may provide us with therapeutic targets and/or monitoring indices for SZ patients.

\section{Antipsychotic-Like Properties of Neurosteroids}

PREG and its metabolites exhibit antipsychotic and cognitive enhancing properties, implying that the lower levels of these neurosteroids may lead to a higher vulnerability to psychosis, whereas the higher levels may reflect a better therapeutic outcome (166).

In general, atypical antipsychotic drugs appear to be better than typical antipsychotics to treat cognitive deficits in SZ (178). In several behavioral paradigms, PROG and ALLO have demonstrated similar antipsychotic-like properties. Increases of PROG and ALLO levels in the brain were observed after clozapine (6, $41,167,179)$ and olanzapine $(7,179,180)$ administration, but not haloperidol (41) administration. Intracerebroventricular administration of ALLO inhibited motor hyperactivity induced by amphetamine (181). Intraperitoneal and intracerebroventricular administration of PROG and ALLO, respectively, could produce inhibition of the conditioned avoidance response in rodents (11). Similar effects were also observed following intraperitoneal injection of antipsychotics olanzapine, risperidone, and haloperidol $(11,182)$. Such antipsychotic effects are likely owing to the interactions among these neurosteroids, GABAergic system, and dopaminergic system as discussed in Section "Modulation of Dopaminergic Activity and Sigma Receptors."

\section{Neurosteroid Trial Studies in Patients}

Since PREG and DHEA exhibit antipsychotic properties, efforts have been undertaken to utilize these neurosteroids as potential adjunctive drugs for treatment of SZ as outlined in Table $\mathbf{1 .}$

During a 6-week randomized, double-blind, placebo-controlled study (183), SZ patients receiving DHEA augmentation (100 mg/day) demonstrated a significant increase in plasma DHEAS levels and concomitant improvements in negative symptoms, but not in depressive or anxiety symptoms. Using a similar clinical intervention protocol, Nachshoni et al. (184) also observed an improvement of extrapyramidal symptoms (EPS) in SZ patients following add-on treatment of DHEA. However, a subsequent study by the same research group failed to demonstrate an overall improvement in symptomatology of chronic SZ patients following an add-on treatment of DHEA (150 mg/day) for 12 -weeks (185). These discrepancies might be due to a number of methodological differences, which could be resolved by a randomized, double-blind, placebo-controlled, crossover trial (186-188). However, a crossover analysis failed to demonstrate improvements on symptom severity, side effects, or quality of life in SZ patients following add-on DHEA treatment $(186,187)$. Using the multiple regression method for predicting sustained attention, memory, and executive function scores (188), however, these same data sets $(186,187)$ suggested that peripheral DHEAS and androstenedione levels may be utilized as positive predictors, whereas DHEA level as negative predictor for cognitive functioning.

On the other hand, several proof-of-concept clinical trials with add-on treatment of PREG were also reported in SZ patients. Findings (189) suggested that PREG exhibited higher therapeutic efficacy than DHEA in psychotic symptoms and cognitive performance from patients with chronic SZ and schizoaffective disorder. Interestingly, patients that received a low dosage (30 mg/day) of PREG demonstrated a significant amelioration in positive symptoms and EPS side effects, as well as improvements in attention and working memory performance $(190,191)$, whereas patients that were treated with a high dose $(200 \mathrm{mg} /$ day $)$ of PREG showed no differences on the outcome variables during the study period (189).

When add-on dose of PREG was increased to $500 \mathrm{mg} /$ day, SZ or schizoaffective patients treated with PREG demonstrated significantly greater reduction in the Scale for the Assessment of Negative Symptoms scores than patients receiving placebo (135). Elevation of serum PREG and ALLO levels predicted the BACS (192) composite scores at 8 weeks in the PREG-treated group. In addition, baseline PREG, PS, and ALLO levels were inversely associated with improvements in the MCCB (192) composite scores. Recently, a similar clinical intervention protocol, but with a larger cohort, was conducted at different study sites $(190,191)$. The results of this study further support a therapeutic role for neurosteroids in alleviating negative symptoms and/or cognitive dysfunctions in SZ.

Thus, clinical interventions that target neurosteroid systems merit further investigation as potential novel treatments for SZ. Moreover, new classes of synthetic neurosteroid analogs that have superior bioavailability and safety profiles compared to natural neurosteroids may be advantageous for clinical use (48).

\section{FUTURE INVESTIGATIONS}

To date, convincing evidence has suggested that neurosteroids can play various roles in the etiology and treatment of many stress-related psychiatric disorders, such as anxiety, depression, and SZ $(193,194)$. In previous studies, only a few neurosteroids of interest were investigated in SZ. In the future, however, it is critical to evaluate more neurosteroids simultaneously in order to 
TABLE 1 | The main indices and results from clinical trials using dehydroepiandrosterone (DHEA) and pregnenolone (PREG) as an augmentation therapy in schizophrneia and schizoaffective disorders.

\begin{tabular}{|c|c|c|c|c|c|c|c|c|c|c|}
\hline \multirow[t]{2}{*}{ Reference } & \multirow[t]{2}{*}{ Patients characteristics } & \multirow[t]{2}{*}{ Antipsychotics } & \multicolumn{3}{|c|}{ Subjects (daily dosage) } & \multirow{2}{*}{$\begin{array}{l}\text { Duration } \\
\text { (weeks) }\end{array}$} & \multicolumn{4}{|c|}{ Significant effects on different aspects as compared to placebo } \\
\hline & & & DHEA & PREG & Placebo & & Symptoms & Cognition & Side effects & $\begin{array}{l}\text { Quality } \\
\text { of life }\end{array}$ \\
\hline Strous et al. (183) & $\begin{array}{l}\mathrm{SZ} \text { inpatients, longer than } \\
\text { 2-year duration, prominent } \\
\text { negative symptoms }\end{array}$ & FGAs, SGAs & 15 (100 mg) & - & 12 & 6 & $\begin{array}{l}\text { Negative, depressive } \\
\text { and anxiety } \\
\text { symptoms }\end{array}$ & No data & No data & No data \\
\hline Nachshoni et al. (184) & Inpatients with SZ/SA & FGAs, SGAs & 15 (100 mg) & - & 15 & 1 & No effect & No data & $\begin{array}{l}\text { Extrapyramidal } \\
\text { symptoms particularly } \\
\text { Parkinson-like } \\
\text { symptoms }\end{array}$ & No data \\
\hline Strous et al. (185) & Stable chronic SZ patients & Olanzapine & 16 (150 mg) & - & 15 & 12 & No effect & No effect & No effect & No effect \\
\hline $\begin{array}{l}\text { Ritsner et al., Strous } \\
\text { et al., and Ritsner and } \\
\text { Strous (186-188) }\end{array}$ & $\begin{array}{l}\text { Inpatients and } \\
\text { outpatients with SZ }\end{array}$ & FGAs, SGAs & 55 (200 mg) & - & 55 & 6 & No effect & $\begin{array}{l}\text { Sustained attention, } \\
\text { memory and executive } \\
\text { function }\end{array}$ & No effect & No effect \\
\hline Ritsner et al. (189) & Patients with chronic SZ/SA & FGAs, SGAs & 16 (400 mg) & $\begin{array}{l}16(30 \mathrm{mg}) \\
10(200 \mathrm{mg})\end{array}$ & 16 & 8 & Positive symptoms ${ }^{b}$ & $\begin{array}{l}\text { Attention and working } \\
\text { memory performance }\end{array}$ & $\begin{array}{l}\text { Extrapyramidal } \\
\text { symptoms }^{\circ}\end{array}$ & No data \\
\hline Kreinin et al. (190) & Patients with SZ/SA & SGAs & - & $8(500 \mathrm{mg})^{\mathrm{a}}$ & 9 & 8 & No effect & No effect & No effect & No effect \\
\hline $\begin{array}{l}\text { Marx et al. and Ritsner } \\
\text { et al. }(135,191)\end{array}$ & $\begin{array}{l}\text { Out- and inpatients } \\
\text { with recent-onset SZ/SA, } \\
\text { with suboptimal response to } \\
\text { antipsychotics }\end{array}$ & FGAs, SGAs & - & $25(50 \mathrm{mg})$ & 27 & 8 & $\begin{array}{l}\text { Negative symptoms } \\
\text { especially on blunted } \\
\text { affect, avolition and } \\
\text { anhedonia domain } \\
\text { scores }\end{array}$ & Visual attention deficits & No effect & No data \\
\hline Marx et al. (192) & $\begin{array}{l}\text { Outpatient with SZ treated with } \\
\text { an antipsychotic for the } \\
\text { previous } 8 \text { weeks or longer }\end{array}$ & FGAs, SGAs & - & $56(500 \mathrm{mg})^{a}$ & 55 & 8 & No effect & No effect & No effect & $\begin{array}{l}\text { Functional } \\
\text { capacity }\end{array}$ \\
\hline
\end{tabular}

aDosing:100 mg/day for 2 weeks, $300 \mathrm{mg} /$ day for 2 weeks, and $500 \mathrm{mg} /$ day for 4 weeks.

${ }^{\circ}$ Significant for PREG augmentation at $30 \mathrm{mg} /$ day.

'Significant for PREG and DHEA argmentations.

SZ, schizophrenia; SA, schizoaffective disorder; FGAs, first-generation antipsychotics; SGA, second-generation antipsychotics. 
test whether they are integrated with each other within the same PREG-PROG-ALLO pathway or across other related pathways. Although the possible interactions between neurosteroids and the $\mathrm{GABA}_{\mathrm{A}}$ receptor were the primary focus of past studies, interactions of these endogenous molecules with other receptor complexes (e.g., NMDA, dopamine, and sigma-1) also need to be explored in mood disorders and SZ.

Neurosteroids may possess intrinsic antipsychotic properties. Using random controlled trials on different key neurosteroids, several recent pilot studies have already shown promising leads to therapeutic development. However, future studies in larger cohorts addressing the effects of neurosteroids on multiple neurotransmitter receptors and the behavioral consequences of long-term follow-ups are still warranted.

In addition, neuroprotective strategies using exogenous neurosteroids or other compounds (such as $5 \alpha$-R inhibitor) modulating the biosynthesis of neurosteroids $(195,196)$ may alleviate some limitations of current antipsychotic drugs, by reducing the cognitive deficits and negative symptoms, as well as by improving functioning and quality of life in patients with SZ.

\section{REFERENCES}

1. Baulieu EE, Robel P. Neurosteroids: a new brain function? J Steroid Biochem Mol Biol (1990) 37(3):395-403. doi:10.1016/0960-0760(90)90490-C

2. Paul SM, Purdy RH. Neuroactive steroids. FASEB J (1992) 6(6):2311-22. doi:10.1096/fasebj.6.6.1347506

3. Dubrovsky BO. Steroids, neuroactive steroids and neurosteroids in psychopathology. Prog Neuropsychopharmacol Biol Psychiatry (2005) 29(2):169-92. doi:10.1016/j.pnpbp.2004.11.001

4. Reddy DS. Neurosteroids: endogenous role in the human brain and therapeutic potentials. Prog Brain Res (2010) 186:113-37. doi:10.1016/ B978-0-444-53630-3.00008-7

5. Le Mellédo JM, Baker GB. Neuroactive steroids and anxiety disorders. J Psychiatry Neurosci (2002) 27(3):161-5.

6. Marx CE, Shampine LJ, Duncan GE, VanDoren MJ, Grobin AC, Massing MW, et al. Clozapine markedly elevates pregnenolone in rat hippocampus, cerebral cortex, and serum: candidate mechanism for superior efficacy? Pharmacol Biochem Behav (2006) 84(4):598-608. doi:10.1016/j.pbb.2006.07.026

7. Marx CE, Shampine LJ, Khisti RT, Trost WT, Bradford DW, Grobin AC, et al. Olanzapine and fluoxetine administration and coadministration increase rat hippocampal pregnenolone, allopregnanolone and peripheral deoxycorticosterone: implications for therapeutic actions. Pharmacol Biochem Behav (2006) 84(4):609-17. doi:10.1016/j.pbb.2006.07.032

8. Marx CE, Stevens RD, Shampine LJ, Uzunova V, Trost WT, Butterfield MI, et al. Neuroactive steroids are altered in schizophrenia and bipolar disorder: relevance to pathophysiology and therapeutics. Neuropsychopharmacology (2006) 31(6):1249-63. doi:10.1038/sj.npp.1300952

9. Rupprecht R, Koch M, Montkowski A, Lancel M, Faulhaber J, Harting J, et al. Assessment of neuroleptic-like properties of progesterone. Psychopharmacology (Berl) (1999) 143(1):29-38. doi:10.1007/s002130050916

10. Członkowska AI, Zienowicz M, Bidziński A, Maciejak P, Lehner M, Taracha E, et al. The role of neurosteroids in the anxiolytic, antidepressive-and anticonvulsive effects of selective serotonin reuptake inhibitors. Med Sci Monit (2003) 9(11):RA270-5.

11. Ugale RR, Hirani K, Morelli M, Chopde CT. Role of neuroactive steroid allopregnanolone in antipsychotic-like action of olanzapine in rodents. Neuropsychopharmacology (2004) 29(9):1597. doi:10.1038/sj.npp. 1300460

12. Guennoun R, Labombarda F, Gonzalez Deniselle MC, Liere P, De Nicola AF, Schumacher M. Progesterone and allopregnanolone in the central nervous system: response to injury and implication for neuroprotection. J Steroid Biochem Mol Biol (2015) 146:48-61. doi:10.1016/j.jsbmb.2014.09.001

\section{AUTHOR CONTRIBUTIONS}

All the authors participated in the writing of the manuscript. HC and JY were the primary writers. TC and XZ conducted a wide literature review of preclinical and clinical studies and contributed to organizing related references. JY was the senior author of the manuscript and provided overall guidance and feedback on revisions of the manuscript.

\section{FUNDING}

This work was supported in part by Nature Science Foundation of China [NSFC81401113 (HC)], the Specialized Research Fund for the Doctoral Program of Higher Education of China [SRFDP20130162120060 (HC)], Hunan Provincial Natural Science Foundation of China [2017JJ3444 (HC)], the Chinese Scholarship Council for oversea study program (HC), Department of Veterans Affairs [Merit Reviews (JY) and Senior Research Career Scientist Award (JY)], and the VA Pittsburgh Healthcare System, National Institute of Health [MH58141 (JY)].

13. Zhang P, Xie MQ, Ding YQ, Liao M, Qi SS, Chen SX, et al. Allopregnanolone enhances the neurogenesis of midbrain dopaminergic neurons in APPswe/PSEN1 mice. Neuroscience (2015) 290:214-26. doi:10.1016/j. neuroscience.2015.01.019

14. Colciago A, Magnaghi V. Neurosteroids involvement in the epigenetic control of memory formation and storage. Neural Plast (2016) 2016:5985021. doi:10.1155/2016/5985021

15. Mayo W, Dellu F, Robel P, Cherkaoui J, Le Moal M, Baulieu EE, et al. Infusion of neurosteroids into the nucleus basalis magnocellularis affects cognitive processes in the rat. Brain Res (1993) 607(1):324-8. doi:10.1016/0006-8993(93)91524-V

16. Vallée M, Mayo W, Darnaudéry M, Corpéchot C, Young J, Koehl M, et al. Neurosteroids: deficient cognitive performance in aged rats depends on low pregnenolone sulfate levels in the hippocampus. Proc Natl Acad Sci U S A (1997) 94(26):14865-70. doi:10.1073/pnas.94.26.14865

17. Vallée M, Mayo W, Koob GF, Le Moal M. Neurosteroids in learning and memory processes. Int Rev Neurobiol (2001) 46:273-320. doi:10.1016/ S0074-7742(01)46066-1

18. Vallée M, Mayo W, Le Moal M. Role of pregnenolone, dehydroepiandrosterone and their sulfate esters on learning and memory in cognitive aging. Brain Res Brain Res Rev (2001) 37(1-3):301-12. doi:10.1016/S0165-0173(01)00135-7

19. Ladurelle N, Eychenne B, Denton D, Blair-West J, Schumacher M, Robel P, et al. Prolonged intracerebroventricular infusion of neurosteroids affects cognitive performances in the mouse. Brain Res (2000) 858(2):371-9. doi:10.1016/S0006-8993(00)01953-3

20. Strous RD, Spivak B, Yoran-Hegesh R, Maayan R, Averbuch E, Kotler M, et al. Analysis of neurosteroid levels in attention deficit hyperactivity disorder. Int J Neuropsychopharmacol (2001) 4(3):259-64. doi:10.1017/ S1461145701002462

21. MacKenzie EM, Odontiadis J, Le Mellédo JM, Prior TI, Baker GB. The relevance of neuroactive steroids in schizophrenia, depression, and anxiety disorders. Cell Mol Neurobiol (2007) 27(5):541-74. doi:10.1007/ s10571-006-9086-0

22. Longone P, Rupprecht R, Manieri GA, Bernardi G, Romeo E, Pasini A. The complex roles of neurosteroids in depression and anxiety disorders. Neurochem Int (2008) 52(4-5):596-601. doi:10.1016/j.neuint.2007.10.001

23. Luchetti S, Huitinga I, Swaab DF. Neurosteroid and GABA-A receptor alterations in Alzheimer's disease, Parkinson's disease and multiple sclerosis. Neuroscience (2011) 191:6-21. doi:10.1016/j.neuroscience.2011.04.010

24. Howes OD, Kapur S. The dopamine hypothesis of schizophrenia: version III the final common pathway. Schizophr Bull (2009) 35(3):549-62. doi:10.1093/ schbul/sbp006 
25. Carlsson A, Waters N, Holm-Waters S, Tedroff J, Nilsson M, Carlsson ML. Interactions between monoamines, glutamate, and GABA in schizophrenia: new evidence. Annu Rev Pharmacol Toxicol (2001) 41:237-60. doi:10.1146/ annurev.pharmtox.41.1.237

26. Coyle JT. Glutamate and schizophrenia: beyond the dopamine hypothesis. Cell Mol Neurobiol (2006) 26(4-6):365-84. doi:10.1007/s10571-006-9062-8

27. Skosnik PD, Yao JK. From membrane phospholipid defects to altered neurotransmission: is arachidonic acid a nexus in the pathophysiology of schizophrenia? Prostaglandins Leukot Essent Fatty Acids (2003) 69(6):367-84. doi:10.1016/j.plefa.2003.08.008

28. Yao JK, van Kammen DP. Membrane phospholipids and cytokine interaction in schizophrenia. Int Rev Neurobiol (2004) 59:297-326. doi:10.1016/ S0074-7742(04)59012-8

29. Mahadik SP, Yao JK. Phospholipids in schizophrenia. In: Lieberman JA, Stroup TS, Perkins DO, editors. Textbook of Schizophrenia. Washington, DC: The American Psychiatric Publishing, Inc (2006). p. 117-35.

30. Condray R, Yao JK. Cognition, dopamine and bioactive lipids in schizophrenia. Front Biosci (Schol Ed) (2011) 3:298-330.

31. Yao JK, Keshavan MS. Antioxidants, redox signaling, and pathophysiology in schizophrenia: an integrative view. Antioxid Redox Signal (2011) 15(7):2011-35. doi:10.1089/ars.2010.3603

32. Messamore E, Yao JK. Phospholipid, arachidonate and eicosanoid signaling in schizophrenia. Oilseeds Fats Crops Lipids (2016) 23(1):D112. doi:10.1051/ ocl $/ 2015054$

33. Carta MG, Bhat KM, Preti A. GABAergic neuroactive steroids: a new frontier in bipolar disorders? Behav Brain Funct (2012) 8:61. doi:10.1186/ 1744-9081-8-61

34. van Broekhoven F, Verkes RJ. Neurosteroids in depression: a review. Psychopharmacology (Berl) (2003) 165(2):97-110. doi:10.1007/s00213-002-1257-1

35. Aloisi AM, Bonifazi M. Sex hormones, central nervous system and pain. Horm Behav (2006) 50(1):1-7. doi:10.1016/j.yhbeh.2005.12.002

36. Biagini G, Panuccio G, Avoli M. Neurosteroids and epilepsy. Curr Opin Neurol (2010) 23(2):170-6. doi:10.1097/WCO.0b013e32833735cf

37. Lee RW, Tierney E. Hypothesis: the role of sterols in autism spectrum disorder. Autism Res Treat (2011) 2011:653570. doi:10.1155/2011/653570

38. Stoffel-Wagner B. Neurosteroid biosynthesis in the human brain and its clinical implications. Ann N Y Acad Sci (2003) 1007:64-78. doi:10.1196/ annals. 1286.007

39. Mensah-Nyagan AG, Do-Rego JL, Beaujean D, Luu-The V, Pelletier G, Vaudry H. Neurosteroids: expression of steroidogenic enzymes and regulation of steroid biosynthesis in the central nervous system. Pharmacol Rev (1999) 51(1):63-81.

40. Barbaccia ML, Roscetti G, Trabucchi M, Purdy RH, Mostallino MC, Concas A, et al. The effects of inhibitors of GABAergic transmission and stress on brain and plasma allopregnanolone concentrations. Br J Pharmacol (1997) 120(8):1582-8. doi:10.1038/sj.bjp.0701046

41. Barbaccia ML, Affricano D, Purdy RH, Maciocco E, Spiga F, Biggio G, et al. Clozapine, but not haloperidol, increases brain concentrations of neuroactive steroids in the rat. Neuropsychopharmacology (2001) 25:489-97. doi:10.1016/ S0893-133X(01)00254-8

42. Kim YS, Zhang H, Kim HY. Profiling neurosteroids in cerebrospinal fluids and plasma by gas chromatography/electron capture negative chemical ionization mass spectrometry. Anal Biochem (2000) 277(2):187-95. doi:10.1006/ abio. 1999.4384

43. McEwen BS. Non-genomic and genomic effects of steroids on neural activity. TrendsPharmacolSci(1991)12(4):141-7.doi:10.1016/0165-6147(91)90531-V

44. Wang M. Neurosteroids and GABA-A receptor function. Front Endocrinol (2011) 2:44. doi:10.3389/fendo.2011.00044

45. Baulieu EE. Neurosteroids: of the nervous system, by the nervous system, for the nervous system. Recent Prog Horm Res (1997) 52:1-32.

46. Carver CM, Reddy DS. Neurosteroid interactions with synaptic and extrasynaptic GABA (A) receptors: regulation of subunit plasticity, phasic and tonic inhibition, and neuronal network excitability. Psychopharmacology (Berl) (2013) 230(2):151-88. doi:10.1007/s00213-013-3276-5

47. Majewska MD, Harrison NL, Schwartz RD, Barker JL, Paul SM. Steroid hormone metabolites are barbiturate-like modulators of the GABA receptor. Science (1986) 232(4753):1004-7. doi:10.1126/science.2422758

48. Reddy DS, Estes WA. Clinical potential of neurosteroids for CNS disorders. Trends Pharmacol Sci (2016) 7:543-61. doi:10.1016/j.tips.2016.04.003
49. Smith SS. Withdrawal properties of a neuroactive steroid: implications for GABAA receptor gene regulation in the brain and anxiety behavior. Steroids (2002) 67(6):519-28. doi:10.1016/S0039-128X(01)00170-2

50. Rudolph U, Crestani F, Benke D, Brünig I, Benson JA, Fritschy JM, et al. Benzodiazepine actions mediated by specific [gamma]-aminobutyric acidA receptor subtypes. Nature (2000) 404(6778):629. doi:10.1038/35007116

51. Collinson N, Kuenzi FM, Jarolimek W, Maubach KA, Cothliff R, Sur C, et al. Enhanced learning and memory and altered GABAergic synaptic transmis-

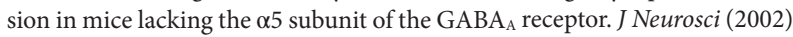
22(13):5572-80. doi:20026436

52. Crestani F, Keist R, Fritschy JM, Benke D, Vogt K, Prut L, et al. Trace fear conditioning involves hippocampal $\alpha 5$ GABAA receptors. Proc Natl Acad Sci U S A (2002) 99(13):8980-5. doi:10.1073/pnas.142288699

53. van Rijnsoever C, Täuber M, Choulli MK, Keist R, Rudolph U, Mohler H. Requirement of $\alpha 5$-GABAA receptors for the development of tolerance to the sedative action of diazepam in mice. J Neurosci (2004) 24(30):6785-90. doi:10.1523/JNEUROSCI.1067-04.2004

54. Yee BK, Hauser J, Dolgov VV, Keist R, Möhler H, Rudolph U, et al. GABA receptors containing the $\alpha 5$ subunit mediate the trace effect in aversive and appetitive conditioning and extinction of conditioned fear. Eur J Neurosci (2004) 20(7):1928-36. doi:10.1111/j.1460-9568.2004.03642.x

55. Gulinello M, Gong QH, Li X, Smith SS. Short-term exposure to a neuroactive steroid increases $\alpha 4$ GABA A receptor subunit levels in association with increased anxiety in the female rat. Brain Res (2001) 910(1-2):55-66. doi:10.1016/S0006-8993(01)02565-3

56. Thompson SA, Whiting PJ, Wafford KA. Barbiturate interactions at the human $\mathrm{GABA}_{\mathrm{A}}$ receptor: dependence on receptor subunit combination. $\mathrm{Br}$ J Pharmacol (1996) 117(3):521-7. doi:10.1111/j.1476-5381.1996.tb15221.x

57. Belelli D, Lambert JJ. Neurosteroids: endogenous regulators of the GABAA receptor. Nat Rev Neurosci (2005) 6(7):565-75. doi:10.1038/nrn1703

58. Puia G, Ducić I, Vicini S, Costa E. Does neurosteroid modulatory efficacy depend on GABAA receptor subunit composition? Receptors Channels (1993) 1(2):135-42.

59. Maitra R, Reynolds JN. Subunit dependent modulation of GABAA receptor function by neuroactive steroids. Brain Res (1999) 819(1-2):75-82. doi:10.1016/S0006-8993(98)01316-X

60. BelelliD, Casula A, Ling A, LambertJJ. Theinfluence of subunit composition on the interaction of neurosteroids with GABA(A) receptors. Neuropharmacology (2002) 43(4):651-61. doi:10.1016/S0028-3908(02)00172-7

61. Mody I. Distinguishing between GABAA receptors responsible for tonic and phasic conductances. Neurochem Res (2001) 26(8-9):907-13. doi:10.1023/A: 1012376215967

62. Farrant M, Nusser Z. Variations on an inhibitory theme: phasic and tonic activation of GABAA receptors. Nat Rev Neurosci (2005) 6(3):215-29. doi:10.1038/nrn1625

63. Whissell PD, Lecker I, Wang DS, Yu J, Orser BA. Altered expression of $\delta \mathrm{GABA}_{\mathrm{A}}$ receptors in health and disease. Neuropharmacology (2015) 88:24-35. doi:10.1016/j.neuropharm.2014.08.003

64. Semyanov A, Walker MC, Kullmann DM, Silver RA. Tonically active GABA A receptors: modulating gain and maintaining the tone. Trends Neurosci (2004) 27(5):262-9. doi:10.1016/j.tins.2004.03.005

65. Coulter DA, Carlson GC. Functional regulation of the dentate gyrus by GABA-mediated inhibition. Prog Brain Res (2007) 163:235-43. doi:10.1016/ S0079-6123(07)63014-3

66. Glykys J, Mann EO, Mody I. Which $\mathrm{GABA}_{\mathrm{A}}$ receptor subunits are necessary for tonic inhibition in the hippocampus? J Neurosci (2008) 28(6):1421-6. doi:10.1523/JNEUROSCI.4751-07.2008

67. Zhu WJ, Wang JF, Krueger KE, Vicini S. Delta subunit inhibits neurosteroid modulation of GABAA receptors. J Neurosci (1996) 16(21):6648-56.

68. Brown N, Kerby J, Bonnert TP, Whiting PJ, Wafford KA. Pharmacological characterization of a novel cell line expressing human alpha(4)beta(3)delta GABA(A) receptors. Br J Pharmacol (2002) 136(7):965-74. doi:10.1038/ sj.bjp. 0704795

69. Wohlfarth KM, Bianchi MT, Macdonald RL. Enhanced neurosteroid potentiation of ternary GABA(A) receptors containing the delta subunit. J Neurosci (2002) 22(5):1541-9.

70. Lambert JJ, Belelli D, Peden DR, Vardy AW, Peters JA. Neurosteroid modulation of GABA A receptors. Prog Neurobiol (2003) 71(1):67-80. doi:10.1016/j. pneurobio.2003.09.001 
71. Hosie AM, Clarke L, da Silva H, Smart TG. Conserved site for neurosteroid modulation of GABA A receptors. Neuropharmacology (2009) 56(1):149-54. doi:10.1016/j.neuropharm.2008.07.050

72. Shen W, Mennerick S, Covey DF, Zorumski CF. Pregnenolone sulfate modulates inhibitory synaptic transmission by enhancing $\mathrm{GABA}(\mathrm{A})$ receptor desensitization. J Neurosci (2000) 20(10):3571-9.

73. Hosie AM, Wilkins ME, Smart TG. Neurosteroid binding sites on GABA A receptors. Pharmacol Ther (2007) 116(1):7-19. doi:10.1016/j. pharmthera.2007.03.011

74. Purdy RH, Morrow AL, Blinn JR, Paul SM. Synthesis, metabolism, and pharmacological activity of 3 alpha-hydroxy steroids which potentiate GABA-receptor-mediated chloride ion uptake in rat cerebral cortical synaptoneurosomes. J Med Chem (1990) 33(6):1572-81. doi:10.1021/jm00168a008

75. Zorumski CF, Mennerick S, Isenberg KE, Covey DF. Potential clinical uses of neuroactive steroids. Drugs (2000) 3(9):1053-63.

76. Ragagnin G, Rahman M, Zingmark E, Stromberg J, Lundgren P, Wang M, et al. Structure activity relationship of GABAA-steroids antagonists. 4th International Meeting-Steroids and Nervous System. Torino, Italy (2007). p. 197.

77. Qian M, Krishnan K, Kudova E, Li P, Manion BD, Taylor A, et al. Neurosteroid analogues. 18. Structure-activity studies of ent-steroid potentiators of $\gamma$-aminobutyric acid type A receptors and comparison of their activities with those of alphaxalone and allopregnanolone. J Med Chem (2014) 57(1):171-90. doi:10.1021/jm401577c

78. Wang C, Marx CE, Morrow AL, Wilson WA, Moore SD. Neurosteroid modulation of GABAergic neurotransmission in the central amygdala: a role for NMDA receptors. Neurosci Lett (2007) 415(2):118-23. doi:10.1016/j. neulet.2007.01.004

79. Korinek M, Kapras V, Vyklicky V, Adamusova E, Borovska J, Vales K, et al. Neurosteroid modulation of N-methyl-D-aspartate receptors: molecular mechanism and behavioral effects. Steroids (2011) 76(13):140918. doi:10.1016/j.steroids.2011.09.002

80. Wu FS, Gibbs TT, Farb DH. Pregnenolone sulfate: a positive allosteric modulator at the N-methyl-D-aspartate receptor. Mol Pharmacol (1991) 40(3):333-6.

81. Mienville JM, Vicini S. Pregnenolone sulfate antagonizes GABA A receptor-mediated currents via a reduction of channel opening frequency. Brain Res (1989) 489(1):190-4. doi:10.1016/0006-8993(89)90024-3

82. Horak M, Vlcek K, Chodounska H, Vyklicky L Jr. Subtype-dependence of Nmethyl-D-aspartate receptor modulation by pregnenolone sulfate. Neuroscience (2006) 137(1):93-102. doi:10.1016/j.neuroscience.2005.08.058

83. Park-Chung M, Wu FS, Farb DH. 3 Alpha-hydroxy-5 beta-pregnan-20-one sulfate: a negative modulator of the NMDA-induced current in cultured neurons. Mol Pharmacol (1994) 46(1):146-50.

84. Park-Chung M, Malayev A, Purdy RH, Gibbs TT, Farb DH. Sulfated and unsulfated steroids modulate gamma-aminobutyric acid A receptor function through distinct sites. Brain Res (1999) 830(1):72-87. doi:10.1016/ S0006-8993(99)01381-5

85. Di Paolo T, Lévesque D, Daigle M. A physiological dose of progesterone affects rat striatum biogenic amine metabolism. Eur J Pharmacol (1986) 125(1):11-6. doi:10.1016/0014-2999(86)90077-4

86. Petitclerc M, Bédard PJ, Di Paolo T. Progesterone releases dopamine in male and female rat striatum: a behavioral and microdialysis study. Prog Neuropsychopharmacol Biol Psychiatry (1995) 19(3):491-7. doi:10.1016/ 0278-5846(95)00029-U

87. Dazzi L, Serra M, Seu E, Cherchi G, Pisu MG, Purdy RH, et al. Progesterone enhances ethanol-induced modulation of mesocortical dopamine neurons: antagonism by finasteride. J Neurochem (2002) 83(5):1103-9. doi:10.1046/j. 1471-4159.2002.01218.x

88. Van Wingen GA, Van Broekhoven F, Verkes RJ, Petersson KM, Bäckström T, Buitelaar JK, et al. Progesterone selectively increases amygdala reactivity in women. Mol Psychiatry (2008) 13(3):325-33. doi:10.1038/sj.mp.4002030

89. Callier S, Morissette M, Grandbois M, Pélaprat D, Di Paolo T. Neuroprotective properties of 17beta-estradiol, progesterone, and raloxifene in MPTP C57Bl/6 mice. Synapse (2001) 41(2):131-8. doi:10.1002/syn.1067

90. Motzo C, Porceddu ML, Maira G, Flore G, Concas A, Dazzi L, et al. Inhibition of basal and stress-induced dopamine release in the cerebral cortex and nucleus accumbens of freely moving rats by the neurosteroid allopregnanolone. J Psychopharmacol (1996) 10(4):266-72. doi:10.1177/026988119601000402
91. Laconi MR, Cabrera RJ. Effect of centrally injected allopregnanolone on sexual receptivity, luteinizing hormone release, hypothalamic dopamine turnover, and release in female rats. Endocrine (2002) 17(2):77-83. doi:10.1385/ ENDO:17:2:077

92. Tenn CC, Niles LP. Sensitization of G protein-coupled benzodiazepine receptors in the striatum of 6-hydroxydopamine-lesioned rats. J Neurochem (1997) 69(5):1920-6. doi:10.1046/j.1471-4159.1997.69051920.x

93. Rougé-Pont F, Mayo W, Marinelli M, Gingras M, Le Moal M, Piazza PV. The neurosteroid allopregnanolone increases dopamine release and dopaminergic response to morphine in the rat nucleus accumbens. Eur J Neurosci (2002) 16(1):169-73. doi:10.1046/j.1460-9568.2002.02084.x

94. Brandon N, Jovanovic J, Moss S. Multiple roles of protein kinases in the modulation of $\gamma$-aminobutyric acid A receptor function and cell surface expression. Pharmacol Ther (2002) 94(1-2):113-22. doi:10.1016/ S0163-7258(02)00175-4

95. Adams JM, Thomas P, Smart TG. Modulation of neurosteroid potentiation by protein kinases at synaptic-and extrasynaptic-type GABA A receptors. Neuropharmacology (2015) 88:63-73. doi:10.1016/j.neuropharm.2014.09.021

96. Lobb CJ, Wilson CJ, Paladini CA. A dynamic role for GABA receptors on the firing pattern of midbrain dopaminergic neurons. J Neurophysiol (2010) 104(1):403-13. doi:10.1152/jn.00204.2010

97. Su TP, London ED, Jaffee JH. Steroid binding at sigma receptors suggesting a link between endocrine, nervous and immune systems. Science (1988) 240(4849):219-21. doi:10.1126/science.2832949

98. Maurice T, Roman FJ, Privat A. Modulation by neurosteroids of the in vivo (+)-[3H]SKF-10,047 binding to $\sigma 1$ receptors in the mouse forebrain. JNeurosci Res (1996) 46(6):734-43. doi:10.1002/ (SICI)1097-4547(19961215)46:6<734:AID-JNR10>3.0.CO;2-U

99. Monnet FP, Mahé V, Robel P, Baulieu EE. Neurosteroids, via sigma receptors, modulate the $[3 \mathrm{H}]$ norepinephrine release evoked by $\mathrm{N}$-methyl-D-aspartate in the rat hippocampus. Proc Natl Acad Sci U S A (1995) 92(9):3774-8. doi:10.1073/pnas.92.9.3774

100. Benes FM. Emerging principles of altered neural circuitry in schizophrenia. Brain Res Rev (2000) 31(2-3):251-69. doi:10.1016/S0165-0173(99)00041-7

101. PlitmanE, NakajimaS, dela Fuente-SandovalC, Gerretsen P, ChakravartyMM, Kobylianskii J, et al. Glutamate-mediated excitotoxicity in schizophrenia: a review. Eur Neuropsychopharmacol (2014) 24(10):1591-605. doi:10.1016/j. euroneuro.2014.07.015

102. Deutsch S, Rosse RB, Schwartz BL, Mastropaolo J. A revised excitotoxic hypothesis of schizophrenia: therapeutic implications. Clin Neuropharmacol (2001) 24(1):43-9. doi:10.1097/00002826-200101000-00008

103. Wojtal K, Trojnar MK, Czuczwar SJ. Endogenous neuroprotective factors: neurosteroids. Pharmacol Rep (2006) 58(3):335-40.

104. Borowicz KK, Piskorska B, Banach M, Czuczwar SJ. Neuroprotective actions of neurosteroids. Front Endocrinol (2011) 2:50. doi:10.3389/fendo.2011.00050

105. Gursoy E, Cardounel A, Kalimi M. Pregnenolone protects mouse hippocampal (HT-22) cells against glutamate and amyloid beta protein toxicity. Neurochem Res (2001) 26(1):15-21. doi:10.1023/A:1007668213330

106. Hsu HJ, Liang MR, Chen CT, Chung BC. Pregnenolone stabilizes microtubules and promotes zebrafish embryonic cell movement. Nature (2006) 439(7075):480-3. doi:10.1038/nature04436

107. Fontaine-LenoirV, ChambraudB, Fellous A, DavidS, DuchossoyY, BaulieuEE, et al. Microtubule-associated protein 2(MAP2) is a neurosteroid receptor. Proc Natl Acad Sci U S A (2006) 103(12):4711-6. doi:10.1073/pnas.0600113103

108. Koenig HL, Schumacher M, Ferzaz B, Thi AN, Ressouches A, Guennoun R, et al. Progesterone synthesis and myelin formation by Schwann cells. Science (1995) 268(5216):1500-3. doi:10.1126/science.7770777

109. Lapchak PA, Chapman DF, Nunez SY, Zivin JA. Dehydroepiandrosterone sulfate is neuroprotective in a reversible spinal cord ischemia model. Stroke (2000) 31(8):1953-6; discussion 1957. doi:10.1161/01.STR.31.8.1953

110. Mao X, Barger SW. Neuroprotection by dehydroepiandrosteronesulfate: role of an NF kappa-like factor. Neuroreport (1998) 9(4):759-63. doi:10.1097/00001756-199803090-00036

111. De Nicola AF, Gonzalez SL, Labombarda F, González Deniselle MC, Garay L, Guennoun R, et al. Progesterone treatment of spinal cord injury. J Mol Neurosci (2006) 28(1):3-15. doi:10.1385/JMN:28:1:3

112. Roof RL, Duvdevani R, Braswell L, Stein DG. Progesterone facilitates cognitive recovery and reduces secondary neuronal loss caused by cortical 
contusion injury in male rats. Exp Neurol (1994) 129(1):64-9. doi:10.1006/ exnr.1994.1147

113. Labombarda F, González Deniselle MC, De Nicola AF, González SL. Progesterone and the spinal cord: good friends in bad times. Neuroimmunomodulation (2010) 17(3):146-9. doi:10.1159/000258709

114. Ciriza I, Azcoitia I, Garcia-Segura LM. Reduced progesterone metabolites protect rat hippocampal neurones from kainic acid excitotoxicity in vivo. J Neuroendocrinol (2004) 16(1):58-63. doi:10.1111/j.1365-2826.2004.01121.x

115. Ishihara Y, Kawami T, Ishida A, Yamazaki T. Allopregnanolone-mediated protective effects of progesterone on tributyltin-induced neuronal injury in rat hippocampal slices. JSteroid Biochem Mol Biol (2013) 135:1-6. doi:10.1016/j.jsbmb.2012.12.013

116. Alessandri JM, Extier A, Langelier B, Perruchot MH, Heberden C, Guesnet P, et al. Estradiol favors the formation of eicosapentaenoic acid $(20: 5 n-3)$ and $n-3$ docosapentaenoic acid (22:5n-3) from alpha-linolenic acid (18:3n-3) in SH-SY5Y neuroblastoma cells. Lipids (2008) 43(1):19-28. doi:10.1007/s11745-007-3117-6

117. Bradley AJ, Dinan TG. A systematic review of hypothalamic-pituitary-adrenal axis function in schizophrenia: implications for mortality. J Psychopharmacol (2010) 24(4 Suppl):91-118. doi:10.1177/1359786810385491

118. Ryan MC, Thakore JH. Physical consequences of schizophrenia and its treatment: the metabolic syndrome. Life Sci (2002) 71(3):239-57. doi:10.1016/ S0024-3205(02)01646-6

119. Thompson JL, Pogue-Geile MF, Grace AA. Developmental pathology, dopamine, and stress: a model for the age of onset of schizophrenia symptoms. Schizophr Bull (2004) 30(4):875-900. doi:10.1093/oxfordjournals.schbul. a007139

120. Purdy RH, Morrow AL, Moore PH Jr, Paul SM. Stress-induced elevations of gamma-aminobutyric acid type A receptor-active steroids in the rat brain. Proc Natl Acad Sci U S A (1991) 88(10):4553-7. doi:10.1073/pnas.88.10.4553

121. Barbaccia ML, Roscetti G, Trabucchi M, Cuccheddu T, Concas A, Biggio G. Neurosteroids in the brain of handling-habituated and naive rats: effect of $\mathrm{CO}_{2}$ inhalation. Eur J Pharmacol (1994) 261(3):317-20. doi:10.1016/0014-2999(94)90123-6

122. Barbaccia ML, Roscetti G, Trabucchi M, Mostallino MC, Concas A, Purdy RH, et al. Time-dependent changes in rat brain neuroactive steroid concentrations and $\mathrm{GABA}_{\mathrm{A}}$ receptor function after acute stress. Neuroendocrinology (1996) 63(2):166-72. doi:10.1159/000126953

123. Barbaccia ML, Roscetti G, Bolacchi F, Concas A, Mostallino MC, Purdy RH, et al. Stress-induced increase in brain neuroactive steroids: antagonism by abecarnil. Pharmacol Biochem Behav (1996) 54(1):205-10. doi:10.1016/0091-3057(95)02133-7

124. Vallée M, Rivera JD, Koob GF, Purdy RH, Fitzgerald RL. Quantification of neurosteroids in rat plasma and brain following swim stress and allopregnanolone administration using negative chemical ionization gas chromatography/mass spectrometry. Anal Biochem (2000) 287(1):153-66. doi:10.1006/ abio.2000.4841

125. Higashi T, Takido N, Shimada K. Studies on neurosteroids XVII. Analysis of stress induced changes in neurosteroid levels in rat brains using liquid chromatography-electron capture atmospheric pressure chemical ionization-mass spectrometry. Steroids (2005) 70(1):1-11. doi:10.1016/j.steroids.2004. 08.001

126. Crestani F, Lorez M, Baer K, Essrich C, Benke D, Laurent JP, et al. Decreased $\mathrm{GABA}_{\mathrm{A}}$-receptor clustering results in enhanced anxiety and a bias for threat cues. Nat Neurosci (1999) 2(9):833-9. doi:10.1038/12207

127. Majewska MD. Neurosteroids: endogenous bimodal modulators of the $\mathrm{GABA}_{\mathrm{A}}$ receptor Mechanism of action and physiological significance. Prog Neurobiol (1992) 38(4):379-95. doi:10.1016/0301-0082(92)90025-A

128. Serra M, Pisu MG, Littera M, Papi G, Sanna E, Tuveri F, et al. Social isolation-induced decrease in both the abundance of neuroactive steroids and $\mathrm{GABA}_{\mathrm{A}}$ receptor function in rat brain. J Neurochem (2000) 75(2):732-40. doi:10.1046/j.1471-4159.2000.0750732.x

129. Dong E, Matsumoto K, Uzunova V, Sugaya I, Takahata H, Nomura H, et al. Brain 5 alpha-dihydroprogesterone and allopregnanolone synthesis in a mouse model of protracted social isolation. Proc Natl Acad Sci U S A (2001) 98(5):2849-54. doi:10.1073/pnas.051628598

130. Matsumoto K, Pinna G, Puia G, Guidotti A, Costa E. Social isolation stress-induced aggression in mice: a model to study the pharmacology of neurosteroidogenesis. Stress (2005) 8(2):85-93. doi:10.1080/10253890500159022
131. Cai HL, Jiang P, Tan QY, Dang RL, Tang MM, Xue Y, et al. Therapeutic efficacy of atypical antipsychotic drugs by targeting multiple stress-related metabolic pathways. Transl Psychiatry (2017) 7(5):e1130. doi:10.1038/tp.2017.94

132. Herman JP, Adams D, Prewitt C. Regulatory changes in neuroendocrine stress integrative circuitry produced by a variable stress paradigm. Neuroendocrinology (1995) 61(2):180-90. doi:10.1159/000126839

133. Crowley SK, Girdler SS. Neurosteroid, GABAergic and hypothalamic pituitary adrenal (HPA) axis regulation: what is the current state of knowledge in humans? Psychopharmacology (Berl) (2014) 231(17):3619-34. doi:10.1007/ s00213-014-3572-8

134. Wang JM, Johnston PB, Ball BG, Brinton RD. The neurosteroid allopregnanolone promotes proliferation of rodent and human neural progenitor cells and regulates cell-cycle gene and protein expression. J Neurosci (2005) 25(19):4706-18. doi:10.1523/JNEUROSCI.4520-04.2005

135. Marx CE, Keefe RS, Buchanan RW, Hamer RM, Kilts JD, Bradford DW, et al. Proof-of-concept trial with the neurosteroid pregnenolone targeting cognitive and negative symptoms in schizophrenia. Neuropsychopharmacology (2009) 34(8):1885-903. doi:10.1038/npp.2009.26

136. Borges S, Gayer-Anderson C, Mondelli V. A systematic review of the activity of the hypothalamic-pituitary-adrenal axis in first episode psychosis. Psychoneuroendocrinology (2013) 38(5):603-11. doi:10.1016/j. psyneuen.2012.12.025

137. Abi-Dargham A. Schizophrenia: overview and dopamine dysfunction. J Clin Psychiatry (2014) 75(11):e31. doi:10.4088/JCP.13078tx2c

138. de Jonge JC, Vinkers CH, Hulshoff Pol HE, Marsman A. GABAergic mechanisms in schizophrenia: linking postmortem and in vivo studies. Front Psychiatry (2017) 8:118. doi:10.3389/fpsyt.2017.00118

139. Rudolph U, Möhler H. GABAA receptor subtypes: therapeutic potential in down syndrome, affective disorders, schizophrenia, and autism. Annu Rev Pharmacol Toxicol (2014) 54:483-507. doi:10.1146/annurev-pharmtox011613-135947

140. Fatemi SH, Folsom TD, Thuras PD. GABA $A_{A}$ and $G_{A B A}$ receptor dysregulation in superior frontal cortex of subjects with schizophrenia and bipolar disorder. Synapse (2017) 71:e21973. doi:10.1002/syn.21973

141. Ritsner M, Maayan R, Gibel A, Weizman A. Differences in blood pregnenolone and dehydroepiandrosterone levels between schizophrenia patients and healthy subjects. Eur Neuropsychopharmacol (2007) 5:358-65. doi:10.1016/j. euroneuro.2006.10.001

142. Breier A, Buchanan RW. The effects of metabolic stress on plasma progesterone in healthy volunteers and schizophrenic patients. Life Sci (1992) 51(19):1527-34. doi:10.1016/0024-3205(92)90563-5

143. Shirayama Y, Hashimoto K, Suzuki Y, Higuchi T. Correlation of plasma neurosteroid levels to the severity of negative symptoms in male patients with schizophrenia. SchizophrRes (2002) 58(1):69-74. doi:10.1016/S0920-9964(01)00367-X

144. Taherianfard M, Shariaty M. Evaluation of serum steroid hormones in schizophrenic patients. Indian J Med Sci (2004) 58(1):3-9.

145. Tourney G, Hatfield L. Plasma androgens in male schizophrenics. Arch Gen Psychiatry (1972) 27(6):753-5. doi:10.1001/archpsyc.1972.01750300025004

146. Oertel GW, Benes P, Schirazi M, Holzmann H, Hoffmann G. Interaction between dehydroepiandrosterone, cyclic adenosine-3', 5'-monophosphate and glucose-6-phosphate-dehydrogenase in normal and diseased subjects. Experientia (1974) 30(8):872-3. doi:10.1007/BF01938331

147. Howard JS III. Severe psychosis and the adrenal androgens. Integr Physiol Behav Sci (1992) 27(3):209-15. doi:10.1007/BF02690893

148. di Michele F, Caltagirone C, Bonaviri G, Romeo E, Spalletta G. Plasma dehydroepiandrosterone levels are strongly increased in schizophrenia. J Psychiatr Res (2005) 39(3):267-73. doi:10.1016/j.jpsychires.2004.08.005

149. Strous RD, Maayan R, Lapidus R, Goredetsky L, Zeldich E, Kotler M, et al. Increased circulatory dehydroepiandrosterone and dehydroepiandrosterone-sulphate in first-episode schizophrenia: relationship to gender, aggression and symptomatology. Schizophr Res (2004) 71(2-3):427-34. doi:10.1016/j.schres.2004.03.005

150. Beyazyüz M, Albayrak Y, Beyazyüz E, Unsal C, Göka E. Increased serum dehydroepiandrosterone sulfate in the first episode but not in subsequent episodes in male patients with schizophrenia. Neuropsychiatr Dis Treat (2014) 10:687-93. doi:10.2147/NDT.S61406

151. Bicikova M, Hill M, Ripova D, Mohr P, Hampl R. Determination of steroid metabolome as a possible tool for laboratory diagnosis of schizophrenia. J Steroid Biochem Mol Biol (2013) 133:77-83. doi:10.1016/j.jsbmb.2012.08.009 
152. Hechter O, Grossman A, Chatterton RT Jr. Relationship of dehydroepiandrosterone and cortisol in disease. Med Hypotheses (1997) 49(1):85-91. doi:10.1016/S0306-9877(97)90258-9

153. Ritsner M, Maayan R, Gibel A, Strous RD, Modai I, Weizman A. Elevation of the cortisol/dehydroepiandrosterone ratio in schizophrenia patients. Eur Neuropsychopharmacol (2004) 14(4):267-73. doi:10.1016/j. euroneuro.2003.09.003

154. Gallagher P, Watson S, Smith MS, Young AH, Ferrier IN. Plasma cortisol-dehydroepiandrosterone (DHEA) ratios in schizophrenia and bipolar disorder. Schizophr Res (2007) 90(1-3):258-65. doi:10.1016/j.schres.2006.11.020

155. Harris DS, Wolkowitz OM, Reus VI. Movement disorder, memory, psychiatric symptoms and serum DHEA levels in schizophrenic and schizoaffective patients. World JBiol Psychiatry (2001) 2(2):99-102. doi:10.3109/15622970109027500

156. Akhondzadeh S. The 5-HT hypothesis of schizophrenia. IDrugs (2001) 4(3):295-300.

157. Thompson AJ, Lummis SC. 5-HT3 receptors. Curr Pharm Des (2006) 12(28):3615-30. doi:10.2174/138161206778522029

158. Hayashi T, Tsai SY, Mori T, Fujimoto M, Su TP. Targeting ligand-operated chaperone sigma-1 receptors in the treatment of neuropsychiatric disorders. Expert Opin Ther Targets (2011) 15(5):557-77. doi:10.1517/14728222.2011. 560837

159. Kantrowitz JT, Javitt DC. N-methyl-d-aspartate (NMDA) receptor dysfunction or dysregulation: the final common pathway on the road to schizophrenia? Brain Res Bull (2010) 83(3-4):108-21. doi:10.1016/j.brainresbull. 2010.04.006

160. Velligan DI, Mahurin RK, Diamond PL, Hazleton BC, Eckert SL, Miller AL. The functional significance of symptomatology and cognitive function in schizophrenia. Schizophr Res (1997) 25(1):21-31. doi:10.1016/ S0920-9964(97)00010-8

161. Gold S, Arndt S, Nopoulos P, O'Leary DS, Andreasen NC. Longitudinal study of cognitive function in first-episode and recent-onset schizophrenia. Am J Psychiatry (1999) 156(9):1342-8.

162. Kuperberg G, Heckers S. Schizophrenia and cognitive function. Curr Opin Neurobiol (2000) 10(2):205-10. doi:10.1016/S0959-4388(00)00068-4

163. Gibbs RB. Long-term treatment with estrogen and progesterone enhances acquisition of a spatial memory task by ovariectomized aged rats. Neurobiol Aging (2000) 21(1):107-16. doi:10.1016/S0197-4580(00)00103-2

164. Singh C, Liu L, Wang JM, Irwin RW, Yao J, Chen S, et al. Allopregnanolone restores hippocampal-dependent learning and memory and neural progenitor survival in aging 3xTgAD and nonTg mice. Neurobiol Aging (2012) 33(8):1493-506. doi:10.1016/j.neurobiolaging.2011.06.008

165. Weill-Engerer S, David JP, Sazdovitch V, Liere P, Eychenne B, Pianos A, et al. Neurosteroid quantification in human brain regions: comparison between Alzheimer's and nondemented patients. J Clin Endocrinol Metab (2002) 87(11):5138-43. doi:10.1210/jc.2002-020878

166. Flood JF, Morley JE, Roberts E. Memory-enhancing effects in male mice of pregnenolone and steroids metabolically derived from it. Proc Natl Acad Sci US A (1992) 89(5):1567-71. doi:10.1073/pnas.89.5.1567

167. Akwa Y, Ladurelle N, Covey DF, Baulieu EE. The synthetic enantiomer of pregnenolone sulfate is very active on memory in rats and mice, even more so than its physiological neurosteroid counterpart: distinct mechanisms? Proc Natl Acad Sci U S A (2001) 98(24):14033-7. doi:10.1073/pnas.241503698

168. Jentsch JD, Roth RH. The neuropsychopharmacology of phencyclidine: from NMDA receptor hypofunction to the dopamine hypothesis of schizophrenia. Neuropsychopharmacology (1999) 20(3):201-25. doi:10.1016/ S0893-133X(98)00060-8

169. Kapur S, Seeman P. NMDA receptor antagonists ketamine and PCP have direct effects on the dopamine $\mathrm{D}(2)$ and serotonin 5-HT(2) receptors-implications for models of schizophrenia. Mol Psychiatry (2002) 7(8):837-44. doi:10.1038/sj.mp.4001093

170. Krystal JH, Karper LP, Seibyl JP, Freeman GK, Delaney R, Bremner JD, et al. Subanesthetic effects of the noncompetitive NMDA antagonist, ketamine, in humans. Psychotomimetic, perceptual, cognitive, and neuroendocrine responses. Arch Gen Psychiatry (1994) 51(3):199-214. doi:10.1001/ archpsyc.1994.03950030035004

171. Lahti AC, Koffel B, LaPorte D, Tamminga CA. Subanesthetic doses of ketamine stimulate psychosis in schizophrenia. Neuropsychopharmacology (1995) 13(1):9-19. doi:10.1016/0893-133X(94)00131-I
172. Mathis C, Paul SM, Crawley JN. The neurosteroid pregnenolone sulfate blocks NMDA antagonist-induced deficits in a passive avoidance memory task. Psychopharmacology (Berl) (1994) 116(2):201-6. doi:10.1007/ BF02245063

173. Romeo E, Cheney DL, Zivkovic I, Costa E, Guidotti A. Mitochondrial diazepam-binding inhibitor receptor complex agonists antagonize dizocilpine amnesia: putative role for allopregnanolone. J Pharmacol Exp Ther (1994) 270(1):89-96.

174. Cheney DL, Uzunov D, Guidotti A. Pregnenolone sulfate antagonizes dizocilpine amnesia: role for allopregnanolone. Neuroreport (1995) 6(12):1697-700. doi:10.1097/00001756-199508000-00025

175. Mathis C, Vogel E, Cagniard B, Criscuolo F, Ungerer A. The neurosteroid pregnenolone sulfate blocks deficits induced by a competitive NMDA antagonist in active avoidance and lever-press learning tasks in mice. Neuropharmacology (1996) 35(8):1057-64. doi:10.1016/S0028-3908(96)00041-X

176. Lahti AC, Weiler MA, Tamara Michaelidis BA, Parwani A, Tamminga CA. Effects of ketamine in normal and schizophrenic volunteers. Neuropsychopharmacology (2001) 25(4):455-67. doi:10.1016/S0893-133X (01)00243-3

177. Malhotra AK, Pinals DA, Adler CM, Elman I, Clifton A, Pickar D, et al. Ketamine-induced exacerbation of psychotic symptoms and cognitive impairment in neuroleptic-free schizophrenics. Neuropsychopharmacology (1997) 17(3):141-50. doi:10.1016/S0893-133X(97)00036-5

178. Meltzer HY, McGurk SR. The effects of clozapine, risperidone, and olanzapine on cognitive function in schizophrenia. Schizophr Bull (1999) 25(2):233-55. doi:10.1093/oxfordjournals.schbul.a033376

179. Marx CE, VanDoren MJ, Duncan GE, Lieberman JA, Morrow AL. Olanzapine and clozapine increase the GABAergic neuroactive steroid allopregnanolone in rodents. Neuropsychopharmacology (2003) 28(1):1-13. doi:10.1038/ sj.npp. 1300015

180. Marx CE, Duncan GE, Gilmore JH, Lieberman JA, Morrow AL. Olanzapine increases allopregnanolone in the rat cerebral cortex. Biol Psychiatry (2000) 47(11):1000-4. doi:10.1016/S0006-3223(99)00305-4

181. Khisti RT, Deshpande LS, Chopde CT. The neurosteroid 3 alpha-hydroxy-5 alpha-pregnan-20-one affects dopamine-mediated behavior in rodents. Psychopharmacology (Berl) (2002) 161(2):120-8. doi:10.1007/ s00213-002-1006-5

182. Wadenberg ML, Soliman A, VanderSpek SC, Kapur S. Dopamine D(2) receptor occupancy is a common mechanism underlying animal models of antipsychotics and their clinical effects. Neuropsychopharmacology (2001) 25(5):633-41. doi:10.1016/S0893-133X(01)00261-5

183. Strous RD, Maayan R, Lapidus R, Stryjer R, Lustig M, Kotler M, et al. Dehydroepiandrosterone augmentation in the management of negative, depressive, and anxiety symptoms in schizophrenia. Arch Gen Psychiatry (2003) 60(2):133-41. doi:10.1001/archpsyc.60.2.133

184. Nachshoni T, Ebert T, Abramovitch Y, Assael-Amir M, Kotler M, Maayan R, et al. Improvement of extrapyramidal symptoms following dehydroepiandrosterone (DHEA) administration in antipsychotic treated schizophrenia patients: a randomized, double-blind placebo controlled trial. Schizophr Res (2005) 79(2-3):251-6. doi:10.1016/j.schres.2005.07.029

185. Strous RD, Stryjer R, Maayan R, Gal G, Viglin D, Katz E, et al. Analysis of clinical symptomatology, extrapyramidal symptoms and neurocognitive dysfunction following dehydroepiandrosterone (DHEA) administration in olanzapine treated schizophrenia patients: a randomized, double-blind placebo controlled trial. Psychoneuroendocrinology (2007) 32(2):96-105. doi:10.1016/j.psyneuen.2006.11.002

186. Ritsner MS, Gibel A, Ratner Y, Tsinovoy G, Strous RD. Improvement of sustained attention and visual and movement skills, but not clinical symptoms, after dehydroepiandrosterone augmentation in schizophrenia: a randomized, double-blind, placebo-controlled, crossover trial. J Clin Psychopharmacol (2006) 26(5):495-9. doi:10.1097/01.jcp.0000237942.50270.35

187. Strous RD, Gibel A, Maayan R, Weizman A, Ritsner MS. Hormonal response to dehydroepiandrosterone administration in schizophrenia: findings from a randomized, double-blind, placebo-controlled, crossover study. J Clin Psychopharmacol (2008) 28(4):456-9. doi:10.1097/JCP.0b013e31817 d86de

188. Ritsner MS, Strous RD. Neurocognitive deficits in schizophrenia are associated with alterations in blood levels of neurosteroids: a multiple regression analysis of findings from a double-blind, randomized, placebo-controlled, 
crossover trial with DHEA. J Psychiatr Res (2010) 44(2):75-80. doi:10.1016/j. jpsychires.2009.07.002

189. Ritsner MS, Gibel A, Shleifer T, Boguslavsky I, Zayed A, Maayan R, et al. Pregnenolone and dehydroepiandrosterone as an adjunctive treatment in schizophrenia and schizoaffective disorder: an 8-week, double-blind, randomized, controlled, 2-center, parallel-group trial. J Clin Psychiatry (2010) 71(10):1351-62. doi:10.4088/JCP.09m05031yel

190. Kreinin A, Bawakny N, Ritsner MS. Adjunctive pregnenolone ameliorates the cognitive deficits in recent-onset schizophrenia: an 8-week, randomized, double-blind, placebo-controlled trial. Clin Schizophr Relat Psychoses (2017) 10(4):201-10. doi:10.3371/CSRP.KRBA.013114

191. Ritsner MS, Bawakny H, Kreinin A. Pregnenolone treatment reduces severity of negative symptoms in recent-onset schizophrenia: an 8-week, double-blind, randomized add-on two-center trial. Psychiatry Clin Neurosci (2014) 68(6):432-40. doi:10.1111/pcn.12150

192. Marx CE, Lee J, Subramaniam M, Rapisarda A, Bautista DC, Chan E, et al. Proof-of-concept randomized controlled trial of pregnenolone in schizophrenia. Psychopharmacology (Berl) (2014) 231(17):3647-62. doi:10.1007/ s00213-014-3673-4

193. Zorumski CF, Mennerick S. Neurosteroids as therapeutic leads in psychiatry. JAMA Psychiatry (2013) 70(7):659-60. doi:10.1001/jamapsychiatry. 2013.245
194. Zorumski CF, Paul SM, Izumi Y, Covey DF, Mennerick S. Neurosteroids, stress and depression: potential therapeutic opportunities. Neurosci Biobehav $\operatorname{Rev}$ (2013) 37(1):109-22. doi:10.1016/j.neubiorev.2012.10.005

195. Frau R, Abbiati F, Bini V, Casti A, Caruso D, Devoto P, et al. Targeting neurosteroid synthesis as a therapy for schizophrenia-related alterations induced by early psychosocial stress. Schizophr Res (2015) 168(3):640-8. doi:10.1016/j. schres.2015.04.044

196. Paba S, Frau R, Godar SC, Devoto P, Marrosu F, Bortolato M. Steroid $5 \alpha$-reductase as a novel therapeutic target for schizophrenia and other neuropsychiatric disorders. Curr Pharm Des (2011) 17(2):151-67. doi:10.2174/138161211795049589

Conflict of Interest Statement: The authors declare that the research was conducted in the absence of any commercial or financial relationships that could be construed as a potential conflict of interest.

Copyright $\odot 2018$ Cai, Cao, Zhou and Yao. This is an open-access article distributed under the terms of the Creative Commons Attribution License (CC BY). The use, distribution or reproduction in other forums is permitted, provided the original author(s) and the copyright owner are credited and that the original publication in this journal is cited, in accordance with accepted academic practice. No use, distribution or reproduction is permitted which does not comply with these terms. 